University of Rhode Island

DigitalCommons@URI

Open Access Master's Theses

1977

\title{
A Comparative Study of the Food and Drug Laws of Nigeria and the United States of America
}

Tunde Adenodi

University of Rhode Island

Follow this and additional works at: https://digitalcommons.uri.edu/theses

\section{Recommended Citation}

Adenodi, Tunde, "A Comparative Study of the Food and Drug Laws of Nigeria and the United States of America" (1977). Open Access Master's Theses. Paper 868.

https://digitalcommons.uri.edu/theses/868

This Thesis is brought to you for free and open access by DigitalCommons@URI. It has been accepted for inclusion in Open Access Master's Theses by an authorized administrator of DigitalCommons@URI. For more information, please contact digitalcommons-group@uri.edu. 


\section{A COMPARATIVE STUDY OF THE \\ FOOD AND DRUG LAWS OF NIGERIA AND \\ THE UNITED STATES OF AMERICA}

BY

TUNDE ADENODI

A THESIS SUBMITTED IN PARTIAL FULFILIMENT OF THE REQUIREMENTS FOR THE DECREE OF

MASTER OF SCIENCE

IN

PHARMACY ADMINISTRATION

UNIVERSITY OF RHODE ISLAND 
MASTER OF SCIENCE THESIS

OF

TUNE ADENODI

Approved:

Thesis Committee

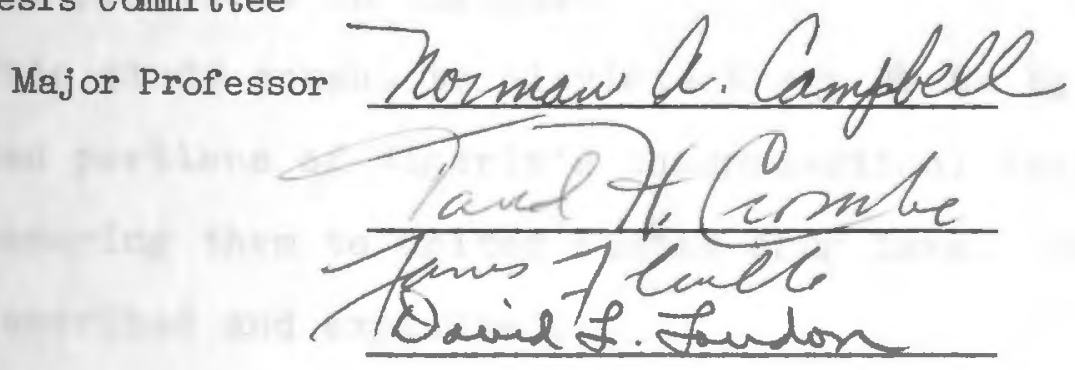

A. Ar michel

Dean of the Graduate School

UNIVERSITY OF RHODE ISLAND

1977 


\section{ABSTRACT}

As the Nigerian economy continues to grow, more multinational pharmaceutical companies are being attracted to this market. However, new companies as well as those presently operating in Nigeria, are faced with a fundamental problem typical for companies doing business in developing countries. This problem is lack of information important in decision making.

There is a general lack of information and understanding of Nigeria's pharmaceutical legislations. Consequently, companies are forced to make many important decisions on the basis of lack of, or at best, incomplete information. In addition, little is presently known about industrial pharmaceutical practices in Nigeria.

This study sought to aleviate the problem by presenting selected portions of Nigeria's pharmaceutical legislations and comparing them to United States drug laws. The two systems were described and explained.

The methodology consisted of two parts. First, the study analyzed major sections of Nigeria's pharmaceutical laws and compared them to United States drug legislations. Major differences were identified and explained.

The second part of the study consisted of gathering primary data from major United States and European pharmaceutical companies doing business in Nigeria. Responses 
obtained were compared to facts secured from the literature search.

Although the research was exploratory in nature rather than conclusive, the following conditions appear to exist,

1. There is a general lack of understanding of the Nigerian Food and Drug laws.

2. The laws themselves appear to be confusing with numerous loopholes.

3. The Nigerian legal environment is less stringent than in the United States.

4. Specifically, drug introduction legisiation was found to be much less stringent in Nigeria than in the United States.

5. Drug Registration is not of major concern to pharmaceutical companies in Nigeria. 


\section{TABLE OF CONTENTS}

Page

ABSTRACT

TABLE OF CONTENTS

IIST OF TABLES

Statement of the Problem

Justification

objectives of the study

Methodology

Layout of the Project

II GENERAL INFORMATION ABOUT NIGERIA $\ldots \ldots \ldots \ldots$

Geography

Topography

Climate

People of Nigeria

History of Nigeria

Events in Nigeria Since Independence

in 1960

Government

III MEDICAL AND PHARMACEUTICAL PROFILE ........

The People's Health

Shortage of Health Manpower

Distribution of Health Manpower

Medical Facilities

The Third National Development Plan

(1975-1980): Health

Seeking Medical Help in Nigeria

1. Self Diagnosis and Treatment

2. Native Doctors (Herbalists)

3. Pharmacists and Physicians

References

IV EVOLUTION OF PHARMACEUTICAL IAWS AND

PRACTICE: UNITED STATES AND NIGERIA ........

Evolution of Pharmaceutical Laws in the United States

Analysis of Significant Developments References 
A Comparison of Major Aspects of U.S. and Nigerian Pharmaceutical Laws Product $\mathrm{S}$ tandards Effects of the Food and Drug Decree and the FDA Regulations

Pricing

Distribution and Restrictive Sale 1. OTC Drugs

2. Prescription Drugs a) Dangerous Drugs Act

b) Importation and Exportation

c) Sale and Distribution

Food and Drug Decree of 1974

Promotion and Advertising References

VI SURVEY OF PHARMACEUTICAL COMPANIES ........

Company Profile

Government Restraints on Marketing

1. Approval of Drugs Before Marketing

2. Company's Liaison Officer with Government

Tests Required on Products Before Marketing in Nigeria

Rate of Drug Approval in Both Countries U.S. Unapproved Drugs in Nigeria Acceptability of U.S. Supplied Data Comparison Between the Two Systems

VII CONCLUSION ......................

General Differences

Medical and Pharmaceutical Practice

Government Controls

Attitudes of Participants

Recommendation for Further studies

APPENDIX 1. Letter of Introduction .............

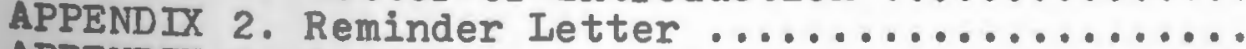




\section{LIST OF TABLES}

Table

Page

1. Reported Cases and Deaths from Notifiable

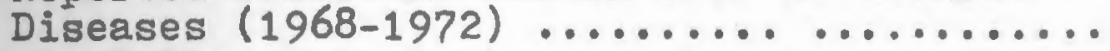

2. Health Manpower in Nigeria (1962-1980) .....

3. Distribution of State Employed Physicians ..

4. Declining Number of New Drug Introduction (1957-1975) ......................

5. Drug Approval Rates in the United States ... 


\section{INTRODUCTION}

\section{Thent of the Problem}

All areas of the pharmaceutical industry are constantly reminded of the controls imposed by government. It is even more so in the United States where there are relatively more accommodating conditions such as those existing in developing nations of the world, particularly Nigeria. As manufacturers move their technology to these areas, they face greater challenges for which they are unprepared, and they are forced to make changes in their policies and strategies as conditions dictate.

There is an abundance of research information on the United States pharmaceutical industry. For example, much research has been done in areas of manufacturing, distribution and promotion. In addition, these functions have frequently been studies in relation to prevailing legal environments at the time. Unfortunately, there has been a great lack of research data on the developing areas of the world. For example, this student examined the research library of one of the largest pharmaceutical companies in the world in early 1976, and found very little information on developing countries. The Marketing Research Division of the company admitted that this was the most difficult problem faced by its company in its operation in Nigeria. Because of Nigeria's 
status as a "third world country," researchers have ignored its pharmaceutical problems. Therefore, managers have been forced to depend heavily on their intuition in making important marketing decisions in Nigeria and developing countries.

Moreover, it is difficult to make decisions about Nigerian problems based on experience in other countries because of its uniqueness. It is unique because of its position in Africa. It is perhaps the richest and certainly the most populous country in Africa; and it is the single largest potential market on that continent. For these reasons, it has attracted the attention of international marketers. As it becomes increasingly important for pharmaceutical companies to understand fully all aspects of the environment within which they must operate.

Since these pharmaceutical companies have to operate within the provisions of Nigerian laws, research into the legal environment surrounding Nigeria's pharmaceutical industry will help fill the vacuum currently existing.

By giving a description of the Nigerian market and the laws that guide it and relating this in terms of the American pharmaceutical laws, manufacturers and marketers will be better equiped to make good operational decisions and also avoid undue risks.

On looking critically at various Nigerian laws, it can be seen that the basic tie between the United States as a former British colony and Nigeria as a more recent independent 
nation of the British Empire, exists. It is even more obvious in the areas of pharmaceutical laws. On the other hand there is a distinction between the two systems which is unique to each country. This study is designed to identify the similarities between United States and Nigerian drug laws and to help explain the differences between the two systems. In addition, the study will explore the influence these differing legal systems may have on the multinational pharmaceutical marketer.

Justification

On beginning this study, it was felt that it would be difficult to compare the drug laws of the two systems mainly because of apparent differences in social and cultural histories and more obvious differences in level of technological and scientific development.

However, both countries have a lot in common. For example, both countries are former colonies of the United Kingdom and both have operated under the provisions of the British Common Laws at the initial parts of their respective histories. Indeed, the laws of both countries today are based on the premise of the British Law. Both countries, particularly the United States, have built or are building a strong free enterprise system which encourages free competition.

Nigeria since independence in 1960, and particularly over the last two years has been forging a system closely 
resembling that of the United States; in education, government, acience and technology.

Over the last few years, the trade between these two countries, each a giant in her own geographical region, is enormous and rising. In Nigeria, just as in the United States, much more money and effort are being devoted to wiping out poverty and disease than ever before. Massive education programs have been begun towards this goal, particularly as demonstrated in the Third National Development Plan (19751980). More emphasis will be placed on preventive medical care and environmental health.

It is anticipated that more laws will emerge as Nigerians become more sophisticated in their health demands. Since the pharmaceutical industry has to operate within the boundaries of these laws, it is essential that this study be undertaken in order to identify potential problem areas.

\section{otives of the Study}

1. The study is aimed at finding the similarities and the differences between the pharmaceutical laws of both countries under consideration.

2. To focus the attention of the international pharmaceutical companies on the growing importance of Nigeria as a market for pharmaceuticals in Africa.

3. To point out the inadequacies in the drug laws of Nigeria.

4. To identify the needs of the people in areas of health manpower and health facilities. 
5. To try to relate the laws enacted in Nigeria to the prevailing conditions at the time of enactment.

6. To compare the impact of pharmaceutical laws in both countries particularly as they affect the multinational companies in their operations in Nigeria.

7. To attempt to confirm what has been empirically known for a while, that drug introduction legislation in Nigeria is much easier than in the United States.

8. To explore the influence the differing legal systems may have on the multinational pharmaceutical marketer.

\section{Methodology}

The methodology used for this project involved two facets. The first activity consisted of an extensive literature search into the major relevant areas of the pharmaceutical laws of both countries.

This was done by obtaining several relevant publications from the Embassy of Nigeria in Washington, Nigerian Consulate Gemeral in New York, the U.S. Department of State and the U.S. Department of Commerce. Other relevant data were obtained through written communication with physicians, pharmacists, college professors, and pharmaceutical marketing executives, particularly Pfizer Inc, in New York City. Further important materials were obtained from the U.S. Department of Health, Education and Welfare in Washington.

Using the University library and the Department of Pharmacy Administration library as major sources of information, 
many other books and journals, articles and several publications were used as sources of comparison between the two systems under consideration. Major differences were identified.

It should be noted that no such research of this nature has ever been done and the data obtained, particularly those from Nigeria consist of very many incomplete information on which empirical decisions have been made. This has made it necessary to design the methodology in two parts in order to substantiate many of the things that have been identified in the first part.

The second activity consisted of gathering primary data from a sample of pharmaceutical companies. Respondents were the executives of the international divisions of major pharmaceutical companies in the United States. In Nigeria, General Managers, Managing Directors and Directors of thirteen drug companies were selected.

Considering the geographical locations of the executives. the resources available to the student, in terms of cost and time and the ready availability of a good mailing list for potential participants, it was deemed prudent to conduct the investigation by mail questionnaire.

Fifty-two addresses were extracted from the National Wholesale Druggists Association publication - 1976 Membership Routive Directory. The officers addressed in the United States were Vice Presidents, Presidents and Directors of the International Divisions of the drug companies. The 
thirteen addresses in Nigeria were obtained from the U.S. Bepartment of State publication of the directory of foreign pharmaceutical companies in Nigeria. All thirteen companies have headquarters in either the United States or in European countries. Altogether, a total of sixty-five companies were obtained in both countries.

The quesionnaire was developed and a pretest was conducted among a carefully selected group of pharmaceutical companies in northeastern United States.

The questionnaire was revised and mailed to the sample of companies selected for the survey. Many of the executives wrote back immediately, some refusing to participate in the study as a matter of corporate policy, others indicated that responding to the questions would betray vital trade secrets.

Several calls were made to companies and reminder letters (see appendix) were mailed to them asking for responses. At this time three more companies returned the questionnaires. Further efforts resulted in a return of only one more questionnaire from Nigeria--the only response received from the thirteen mailed to Nigeria,

Altogether, a total of twenty companies responded, only six of which filled out the questionnaire as desired--a response rate of approximately nine percent.

The analysis of the responses is utilized as a finale to the investigation. It has been introduced at this point in order to prepare the reader for the format and design of 
the investigation. The analysis is presented in Chapter VI.

\section{Tut of the Project}

This study consists of seven chapters. The following chapter provides a background information about Nigeria from the colonial days through independence in 1960 to the present.

Chapter III provides a profile of the health care industry and leads on to chapter IV which deals with the evolution of the pharmaceutical laws of the two countries under consideration.

The fifth chapter provides a discussion comparing selected areas of the Nigerian and United States pharmaceutical laws. Chapter VI describes the attitudes of the pharmaceutical companies as found in the survey, and chapter VII summarizes the study's conclusion and provides suggestions for further research. 


\section{GENERAL INFORNATION ABOUT NIGERIA}

\section{Geography}

Nigeria, located on the West Coast of Africa, is bounded on the south by the Gulf of Guinea, on the north by the country of Niger and Chad Republic; on the east by the Cameroon and on the west by the Peoples Republic of Benin, formerly known as Dahomey.

It covers an area of 357,000 square miles, which makes it about the size of California, Nevada and Arizona combined. Thus it is the largest nation on the west of coast of Africa, and with a population of nearly 80 million, it is the most populous country on the continent of Africa. It is estimated that one out of every five Africans, south of the Sahara, is a Nigerian.

\section{Topography}

Four main topographical areas may be distinguished in terms of vegetation and climate:

1. The hot, humid coastal belt of Mangrove Swamp, 10-16 miles wide,

2. The tropical Rain Forest and oil palm bush, 50-100 miles wide north-bound,

3. The relatively dry central plateau of open woodland and savanah, covering the greater part of the northern region and 
4. The semi-desert, bordering the neighboring country of Niger in the extreme north.

\section{Climate}

Nigeria's two main seasons--the dry season and the wet season, can be further classified into four types of seasons, making it comparable to the winter, spring, summer and fall seasons of North America. The winter can be compared to Nigeria's hamattan season between the months of November and February. At this time it is dry, dusty and cold. In contrast to the American winter, it never snows in Nigeria and the coldest it ever gets is perhaps as cold as a beautiful spring morning in the United States.

The three months following the dry season, February. March and April, may be analogous to the American spring season. It is nice and beautiful. It is warm in the day and rather cool at night. Temperatures range between $65^{\circ}$ and $70^{\circ}$ in the south but down in the $50^{\prime} \mathrm{s}$ in the extreme northern part of Nigeria.

The wet season begins earlier in the south in the month of May and overlaps into the dry season much as spring overlaps into early summer in North America. Rainfall varies from 20 inches per annum in the north to as much as 150 inches per annum in the south. The rains taper off around September and yields to the more pleasant fall-like weather when leaves turn brown and wither and grounds become dry and dusty once again. 


\section{1e of Nigeria}

Nigeria forms a conglomerate of heterogeneous tribal groups ever present in any country in Africa. Over 150 tribal groups are represented, with languages that differ from one another much as English differs from French.

This heterogeneity has brought about serious anxiety and fear of domination among Nigeria's minority groups and has been one of Nigeria's main obstacles to forming a strong and united nation. Indeed, it has resulted in one of the most bitter civil wars ever fought on the continent of Africa.

\section{tory of Nigeria}

The area now known as Nigeria has had a long and eventful history even before the colonial period. The northern cities of Kano, Kaduna and Sokoto have had a recorded history dating back to $1100 \mathrm{AD}$. Along with the Bornu Empire in the north east corner, the Hausa Kingdoms in the north have served as the important link between the Islamic haven of Mecca in modern Saudi Arabia and the Yoruba Kingdom of Oyo, in southern Nigeria.

During the 17 th and 18 centuries, the effect of the slave trade and the inter-tribal wars was a disintegration of political edifice of these Kingdoms, particularly those of the Oyo kingdom and the ancient Empire of Benin. The Hausa Emirate of Northern Nigeria was further disintegrated by the Fulani crusader--Usman Dan Fodio, who established the Islamic faith of which about 47 percent of the present Nigerian population belongs. 
The arrival of Europeans in Benin in the 15th and 16 th centuries signalled the beginning of the colonization of Nigeria. In 1885, the British had been widely recognized as an influential power and colonial owner of this part of Africa. In 1900, this territory came under the direct control of the British government.

In 1914 , the 100,000 square miles which was Usman Dan Fodio's territory was united with the southern provinces inlcuding Lagos Colony and called the "Colony and Protectorate of Nigeria."

From 1922 to 1943, Nigerian nationals were incorporated into the government as legislators and executives under the jurisdiction of the British Governor's Cabinet. During this period, successive constitutions legislated by the British government formulated a federal government structure (with powerful federal executive and less so powerful state governments) which has persisted until today.

\section{Migeria since Independence in 1960}

October 1, 1960, marked the turning point in the history of Nigeria when it was granted full independence as a Federation of three disproportionate divisions of Northern Region (over 100,000 square miles in area and more than 50 percent of the population of Nigeria); and both the Eastern and Western Regions of Nigeria which when taken together, constitute less than 50 percent of Nigeria. 
Administration of the country was handed over to the Northern born Abubakar Tafawa Balewa who became the Prime Minister. In 1963. Nigeria broke its last ties with the United Kingdom when it became a Republic.

Tribal and regional tensions mounted as politicians became corrupt and unresponsive to the wishes of the people. Fear of Ibo domination transformed into fear of Hausa domination and Nigeria plunged deeper and deeper into fear chaos and political annihilation. Power struggle mounted at the Federa; level as the Ibo tried to participate in the Federal structure and the Hausa refused to share its political power. The leaderless Yorubas* looked on as the strife plummeted into a bitter and vicious struggle among the politicians.

The climax was reached on January 15, 1966, when a dissident section of the Nigerian Army overthrew the Civilian government of Balewa in a coup-de-tat and brought an Ibo-born Majur-General J.T.U. Aguiyi Ironsi to power. Ironsi abolished the Federal structure and inaugurated in its place a Unitary form of government which in essence put the leadership of the country in the hands of an elite few and threw the country further into uncertainty and fear as thousands of Ibos were murdered in protest in Northern Nigeria.

-Obafemi Awolowo, the respected Yoruba leader was jailed for ten years on charges of treason. 
A counter coup which catapulted a Tiv-born Lt. Col. Yakubu Gowon to power was implemented on July 29, 1966. Ironsi was killed.

Lt. Col. Odumegwu Ojukiwu, the Military Governore of Eastern Nigeria, himself an Ibo, saw this as a means of perpetuating a Northern Dynasy of rulers and refused to give his allegiance to the Gowon regime. On May 27, 1967. Gowon promulgated a decree creating twelve states out of the four main regions. ojukwu responded by proclaiming an Independent state of Biafra from the Eastern Region. War broke out on July 6,1967, and lasted for two and a half years.

After nine years of rule, Gowon's regime was toppled in a bloodless coup by yet another northern-born Brigadier Murtala Mohammed. Mohammed was killed in an unsuccessful coup attempt on February 13, 1976, and was succeeded by Yoruba-born Olusegun Obasanjo, who is the present Nigerian head of state.

\section{Government}

One of the most welcome acts of Gen. Murtala Mohammed before his assasination was the creation of a union of nineteen states* out of the twelve which Gowon had created.

- Because there have been no significant developments in Nigeria's seven new states since their creation, the twelvestate structure will be used throughout the length of this
thesis. 
Nigeria is presently under a military regime headed by Lt. Gen. Olusegun Obasanjo. The Supreme Military Council is the most powerful policy-making body in the absence of

a legislature. The Federal Executive Council performs the role of a Cabinet.

Except that decrees promilgated by the Federal Military Government are beyond judicial review, little has changed in the Federal and State judicial systems since the days of civilian governments.

Barring other significant military uprising, it is hoped that the present government will hand over the administration of the country to the civilians in 0ctober, 1979, as planned. 


\section{MEDICAL AND PHARMACEUTICAL PROFIIE}

\section{People's Health}

In Nigeria where the life expectancy at birth is 39 years ${ }^{1}$ compared to 71.9 years $^{2}$ in the United States, it can be said quite succinctly that the health of the people is not good.

Like in most developing countries of Africa, Latin America and Asia, major causes of morbidity and mortality are due to affliction with preventable diseases such as malaria, tetanus, measles, tuberculosis and meningitis. These diseases along with small pox. "whose eradication in Nigeria by 1980 is considered feadible," dysentary and cholera acoount for 95 percent of all 111 health and deaths in Nigeria by 1974.3 Malaria is the most notorious and remains the most intractable problem because of the wide exposure of the population to the vector-mosquito.

Table I is a list of Nigeria's leading causes of illhealth and death. It represents those cases that were reported between 1968 and 1972. It can be seen from this table that much of Nigeria's 1ll-health and death is caused by preventable diseases, most of which are under control in the United States.

The figures in this table may be quite deceiving. The reported cases are those that occur in cities where facilities 
TABLE 1

REPORTED CASES AND DEATHS FROM NOTIFIABLE DISEASES (1968-1972)

$$
1968 \quad 1969 \quad 1970 \quad 1971 \quad 1972
$$

$\begin{array}{lrrrrrrrrrr}\text { Cholera } & \text { NA* } & \text { NA } & \text { NA } & \text { NA } & \text { NA } & \text { NA } & 11404 & 3095 & 1363 & 96 \\ \text { Small Pox } & 1832 & 164 & 186 & 20 & 79 & 1 & \text { NA } & \text { NA } & \text { NA } & \text { NA } \\ \begin{array}{l}\text { Cerebrospinal } \\ \quad \text { Meningitis }\end{array} & 1879 & 214 & 4291 & 459 & 9712 & 1077 & 7897 & 886 & 5254 & 604 \\ \text { Tuberculosis } & 8952 & 274 & 11710 & 214 & 33279 & 577 & 19344 & 257 & 17584 & 282 \\ \text { Malaria } & 265908 & 265 & 369397 & 413 & 628534 & 1109 & 644494 & 613 & 798344 & 517 \\ \text { Measles } & 49947 & 811 & 45139 & 610 & 53529 & 449 & 88722 & 785 & 84495 & 495 \\ \text { Tetanus } & 1177 & 323 & 1689 & 414 & 3035 & 639 & 2360 & 462 & 2707 & 694\end{array}$

*NA = Not Available.

Source: Federal Ministry of Health, Statistics Division, Lagos, Nigeria. 1974. 
are usually available - and as will be seen later, the number of such cities is very small. Several thousand cases occur in villages and towns that are far from urban areas and hence cannot be reported.

\section{Tige of Health Manpower}

In the period between 1962 and 1972, the number of physicians in Nigeria rose from a scanty 1,354 to 3,112 , reFresenting a doctor to population ratio of approximately $3,100,000$ in 1962 and $5: 100,000$ in 1972.4 Though this represents an increase of more than 100 percent in the 10 years period, it has not yet met the standard of 108100,0005 set by the World Health Organization (WHO) for this part of the world.

The situation is even more critical when consideration is given to the 1,280 or 41 percent of the physicians who are expatrates. 6 Corresponding ratios for dentists in this period were $1: 931,000$ in 1962 to $1: 548,000$ in 1972, a ratio of much less than 1:100,000 people.

The figure for pharmacists is even more critical. In 1962, using figures of Nigeria's Ministry of Economic Development, there were 583 registered pharmacists in Nigeria (including non-practicing pharmacists). Ten years later, there were 1.005 registered pharmacists or a ratio of approximately 1:100,000. 
TABIE 2

HEALTH MANPOWER IN NIGERIA (1962-1980)

\section{YEAR}

POPULATION IN MILIIONS

HEAITH MANPOWER

\section{2}

54

\section{2}

69
1980

81

\begin{tabular}{lcrrrrr} 
HEALTH MANPOWER & $\begin{array}{c}\text { ABSOLUTE* } \\
\text { FIGURES }\end{array}$ & $\begin{array}{c}\text { PER } \\
100,000\end{array}$ & $\begin{array}{c}\text { ABSOLUTE* } \\
\text { FIGURES }\end{array}$ & $\begin{array}{c}\text { PER } \\
100,000\end{array}$ & $\begin{array}{c}\text { ABSOLUTE* } \\
\text { FIGURES }\end{array}$ & $\begin{array}{c}\text { PER } \\
100,000\end{array}$ \\
\hline Physician & 1,354 & 2.5 & 3.112 & 4.5 & 5,760 & 7.0 \\
Dentist & 58 & 0.1 & 126 & 0.2 & 202 & 0.3 \\
Pharmacist & 583 & 0.9 & 1,005 & 1.5 & 2,025 & 2.5 \\
Nurse & 7,105 & 13.0 & 15,682 & 22.7 & 16,730 & 33.0 \\
Radiologist & 68 & 0.1 & 124 & 0.2 & 810 & 1.0 \\
Med Technologist & 71 & 0.1 & 240 & 0.4 & 810 & 1.0 \\
\hline
\end{tabular}

+ Population has been adjusted yearly, using 1963 as base year; 2.7 percent population increase per year (WHO's estimate) 1963 census ( 55.6 milion).

* Figures obtained from Federal Ministry of Economic Development, Statistics Division page 263.

All other figures are extrapolated. 
Using WHO's Verld Directory of Schools of Pharmacy, 1966. a comparison can be made between the United States and African figures, particularly that of Nigeria. In 1963, there were 9,600 pharmacists in the whole continent of Africa, excluding the country of South Africa. At this time African population was about 296 million. This represents a ratio of $3,100,000$. There were only thirteen colleges of pharmacy in the whole oontinent.

Nigerian population at this time was 55.6 million (1963 census). There were 484 actibe pharmacists in the country and one college of pharmacy. In the United States at this time, there were 117,897 pharmacists and a total of 76 colleges of pharmacy. The United States population at this time was about 192 million. Expressing this figure in number of pharmacists per hundred thousand population. Nigeria had three in 1962 to $\mathbf{m i x}$-three in the United States in the same year.

While in 1972 the number of pharmacists in the United States was 132,959 , an increase of nearly 13 percent over 1962 igures, and a ratio of $63: 100,000 ;$ Nigerian figures were more than doubled to about 1,300 but remained at an incredibly low rate of $2: 100,000$.

To bring these figures a little closer home. Rhode Island, the amallest state in the United States, with a population of less than one million in 1972 had a pharmacist to population ratio of 83:100,000, even surpassing the entire United States ratio of $63: 100,000.7$ 


\section{ion of Health Manpower}

of even greater concern is the gross inbalance in the distribution of the available manpower. Only 16.7 percent of the entire population lives in urban areas of 20,000 or more. 8 Most of the health care personnel live in those areas. Indeed, in this student's home town of Ondo in Western States, which has a population of about 100,000 , he knew of only two physicians. One of them was in the only General Hospital in Ondo and the other was engaged in private practice. There were only two pharmacies and perhaps two or three patent medicine stores.

In state capitals and in larger cities there is an overconcentration of health care personnel much as in the United States bigger cities. While the overall physician/population ratio in Nigeria is approximately 4,100,000, in some states the ratio could be as low as less than 1:100,000. Since there are no records of state by state distribution of all physicians in Nigeria, it is being assumed that the distribution of state-employed physicians as illustrated in Table 3, reflects the distribution of all physicians in Nigeria. Moreover, 57 percent of all physicians in Nigeria are employed by the states or the Federal government. 9 Estimating these Plgures from those shown in Table 3 , it can be seen that it ranges in density of 24:100,000 in Lagos state to as low as less than 1:100,000 in North-Western state. It can be seen that the six southern states of West, Lagos, East-Central, Mid-West, and Rivers (except the South-Eastern State) account 
TABLE 3

DISTRIBUTION OF STATE EMPLOYED PHYSICIANS (1972)

STATE

(MILLION) POPULATION*
NUMBER OF

STATE-EMPLOYED PHYS IC IANS
NUMBER PER+ 100,000 PEOPLE

1. WESTERN

13.7

494

4

2. IAGOS

1.9

464

24

3. EAST-CENTRAL

9.3

280

3

4. NORTH-CENTRAL

3.1

114

4

5. MID-WESTERN

3.1

106

3

6. NORMH-EASTERN

9.8

60

1

7. KANO

7.2

53

1

8. BENUE-PLATEAU

5.2

47

1

4.1

46

1

2.0

44

2

11. NORTH-WESTERN

7.1

36

1

12. KWARA

3.4

30

1

\section{9}

1774

4

*xtrapolated from 1963 Census given in Africa, No. 44, April, 1975. p. 23

+Approximate Figures.

Source: IMS WORLD DRUG MARKET MANUAL, SEC. 14.1, 1975 
for approximately 78 percent of all physicians in Nigeria.

According to the 1963 census, cities and towns in Nigeria with population above 70,000 are thirty-eight. Twenty of these are from the Western State. 10 In this state there is Nigeria's second most populous city - Ibadan. With a population of 1.5 million and also serving as the state capital, it has nearly all the Western State establishments and therefore has the majority of all practicing physicians. Lagos, the Nigerian capital, population 1.8 has nearly 28 percent, the highest concentration of all physicians in the entire Federation of Nigeria.

The effect of these figures is to demonstrate a critical shortage of physicians in the six northern states of Nigeria, which together form more than 60 percent of the entire population. With the exception of North-Central State which has a ratio of $4: 100,000$, all the other northern states have well below the ratio of 1:100,000. Kaduna, a city of 300,000 people has the greatest concentration of practicing physicians. Kaduna, of course, is the capital of the NorthCentral state. This maldistribution is also true of all the health care personnel. It is true of dentists and pharmacists alike.

The maldistribution of health personnel is not unique to Nigeria only. It is a problem in the United States as Well. Whington D.C., a city of well over 700,000 people had the highest concentration of active physicians in the United States in 1967.11 It had a physician to population 
ratio of $318,100,000$. Washington D.C. of course, is the capital of the United States. Next to this is New York State with 199, Massachussetts with 181, Colorado with 168, and Rhode Island, with a ratio of $151: 100,000$. On the other end are the states of Alaska with a ratio of 69 , Mississippi with 69; the Commonwealth of Puerto Rico with 68 and the U.S. butlying areas with a ratio of $61,100,000$. It is common knowledge that there is a propensity for higher concentration of active physicians in state capitals and of course, in the Federal Capital as has been seen in the Nigerian figures. The same is true of all other health professionals.

\section{eal Facilities}

Health care centers are basically located in state capitals and few in the large cities. As of 1973, there were 399 hospitals in Nigeria, distributed disproportionately, just as health care personnel were. To compliment these facilities are 130 maternity homes and child centers; 1,600 dispensaries which provide a combined total of 4,920 additional beds.12 As is the case with the staffing of these facilities, the inherent problem of maldistribution exists. The rural areas are the most badly affected, and in some rural areas where there are facilities, services are usually "lopsided, leaving large urban areas without medical attention."13

\section{Flopment Plan $(1975-1980)$ : Health}

The levelopment plan is certainly the most comprehensive 
of all health plans ever made in the history of Nigeria. Top prority is given to the "development and expansion of relevant training institutions in the country to ensure the adequate supply of the needed category of health manpower and their even distribution in the country."14 An admission rate of about 3,000 a year into Nigeria's medical schools is planned for 1980. It is the government's plan to establish Teaching Hospitals in all state capitals in order to have an even deployment of physicians and the para-medical personnel such as pharmacists, laboratory technicians, nurses, etc. Emphasis will be placed on preventable health services such as improved sewage systems, improved drainage systems, and Iusproved environmental sanitation. A total of 1760 milion (\$912 million) is budgeted for the plan period. Porty-one percent of this amount has been allocated for Pederal programs and the rest for state programs.

dical Help in Nigeria

Nigerians usually go through three stages in the process of seeking medical attention during sickness:

\section{Diagnosis and Treatment - Self diagnosis and}

treatment involves several mythical phenomena which are transfered from generation to generation. The problems treated in this manner range from impotency to schizophrenia. Concoctions are made from leaves and tree barks and are usually mixed with alcohol (for better extraction). The dosage regimens are irregular and lack specific measures. But the 
people have confidence in it and, apparently, it works; they often het healed.

tive Doctors (Herbalists) - The native doctors are in line after the process of self-diagnosis and treatment has failed. If the problem continues unabated, it is perhaps one brought on the individual by an angry god or a distant jealous relative. The herbalist is consulted and his recommendations are highly esteemed. A herbalist has been known to perform simple scientific experiments in the process of the diagnosis of diabetes mellitus. He asked his patient to urinate in one corner of his room, after a period of about 10-15 minutes, he would check the spot for ants. A cluster of ants on the urine would suggest the presence of sugar in the urine. He would then taste the urine to confirm the experiment.

The herbalist is usually not educated, but has some attributes whioh are essential for the job. It includes, but is not limited to the following, religion, sacred and acrobatic dances, simple magical charms, incantations, drug lore, mythology and etc. Bundukamara ${ }^{15}$ likens these qualifications to those of the primitive medicine men of the Navaho Indians of the South-West United States. The more charms and incantations the herbalist knows, the more likely he is successful in his practice. A long period of apprenticeship is a must for the potential herbalist. He associates with an older and more experienced herbalist and runs errands and does a lot of the compounding of the various ingredients in his pre- 
ceptor's "pharmacopoea". In this process, he picks up the incantations and charms that form a major integral part of the medicinal practice, and soon he becomes a herbalist himself. According to Kouadvi,16 "... the art of healing is limited to various categories of people who inspire respect, fear and mistrust, " with reference to the herbalists. These, in a few words, explain the qualification of the Nigerian native doctor.

Kouadvi's list of African Traditional Pharmacopoea consists of the followings

(a) Simple or compound species - made with mixtures of leaves or barks;

(b) Packages - made of leaves of trees or papers;

(c) Plant juices - obtained by grinding after squeezing fresh plants;

(d) Alcolature - obtained from roots and barks which have been macerated in gin, rum or any other alcohol;

(e) Pellets and pill - pounded fresh leaves rolled into balls of desired size and dried;

(f) Liniments - made of oil from palm trees, cocoa, sesame;

(g) Throat sashes - mixture of astringent plants or an infusion of such plants.

Contusion, exinding, separation, squeezing, torrefaction and earbonization are used in the process of compounding these meterials.17 Scientific accuracy is not necessary and therapeutic application of these materials vary depending on the Intuition of the herbalist. 
A sick man, down for example ranging from simple bacterial Infection to complications of cancer, is treated in part, with rituals such as invoking the power of the gods, and asking the patient to repeat certain incantations three, seven or twenty-one times, depending on the seriousness of the disease. Directions to patients often inlcude a list of taboos, the violation of which may nullify the effect of the preparation. This is analogous to the practice of the Cherokee Indian tribe of North America, whose taboo list include the followings "... one must not touch a squirell, a dog, a cat, a mountain trout, a woman ...."18

Eric Stone' $\mathbf{s}^{19}$ classification of American Native "materia medica" into three categories can be applied to Nigeria's medicine men of today;

1. Substances effective as carriers of devine power for example, the Apache relied on a piece of cholla cactus hung around the neck to protect children against sickness, just like the American grandmothers used a tiny bag of asafoetida to protect their children.

2. Substances upon which "God" had put a sign as to their intended usefulness - for example, the Hopi used hair-like clematis fibers to treat falling hair, and dusted ashes on burned skin as a healing protective.

3. Substances used for their physiologic actions (emplrically discovered) - the Missouri River tribe used wild mint as a carminative and magnesia salt found in mineral springs as a laxative.

The power of the Nigerian native doctor is immeasurable. Stories have been told of persons whose magical power makes them "dlappear" at the sound of a gun shot, military officers 
who can catch flying bullets and executives whose jobs become "secure" after a visit to the native doctor. Judges are said to have slept and snored in the midst of complicated criminal trials as a result of magical charms cast on them by the accused. Such court cases are said to have been dismissed after several such incident!

Belief in the native doctors is diminishing gradually as Nigerians are becoming increasingly aware of the scientific approach to disease healing. Less confidence is placed on the native doctor's empirical approach. Illness is blamed less on the doing of distant relatives or jealous subordinates. More and more people are turning away from them as Nigerian Iawmakers are pondering on what to do with them. There have been calls for the legislators to ban them from practice. opponents have argued that this would be disastrous especially for people in the rural areas where physicians are inherently absent. Others have called for their certification. But it is difficult to certify a native doctor's credential without having a measuring yardstick on his abilities and capabilities. Many scientists, including Dr. Adeoye Lambo, 20 an ominent psychiatrist with international repute, have called for a joint venture between the native doctors and Nigerian scientists in research into African Medicine. The Nigerian Association of Medical Herbalists ( a group representing the native doctors) has siad that it would like to see the development of traditional medicine side by side with modern methods as in China and Egypt. It said that a ban on their practice 
"... will cause hardship to millions of Nigerian patients and increase the death rate significantly." 21 This statement is further reinforced by the statement of the former Mid-Western State Governor - Brigadier Ogbemudia, who urged the Nigerian Medical Council to conduct research into tradtional medicine. The North-Central State Governor also apported the idea of conducting research into local herbs. 22 While the traditional healers occupy a very unique position in Nigeria's health care system, the prognosis for their continued existence in this role is not very good. Gradually their role is being phased out; not by the Government (which is a more effective way but certainly more controversial), but by the people themselves who have identified a better and less primitive system. Thus, the elimination of their role from the health care team is only a matter of time. step in seeking medical help in Nigeria is a visit to the pharmacist or the physician. The position of the pharmacist in the health team is very important. He is a "Quasi-doctor", just as Bundukamara 23 pointed out. He is sandwiched between the practice of pharmacy and the practice of medicine, whereas, in the United States, the pharmacist serves as a Nddeman between the patient and the physician. As far as drug consumption is concerned, the relationship between patien/s/pharmacists/physicians in Nigeria is a rather more subtle one.

Most patients do not see a pharmacist after a visit to 
the physician. A lot of them do not see the physician after a visit to the pharmacist either. Physicians dispense their oun petscriptions. 24 Several reasons can be conjectured for this practice:

1. Physicians dispense their own prescriptions because of the profit obtained from selling those drugs themselves;

2. Because of the esteem derived from doing so - most Nigerians believe in the physicians power of healing and cannot conceive of the idea of going to a third party to obtain their medicines;

3. Patients usually feel that physicians have not done their jobs properly if they do not receive medication from them;

4. Physicians have 100 percent control over their patients. Other reasons would shed some light on the practice of some of the Nigerian pharmacists:

5. Most physicians believe that their prescriptions are dispensed by persons other than pharmacists whose "... knowledge of medicine is only limite to the name of the package or the bottle." 25

6. Because of the "... unscrupulous pharmacists who would sell deadly and untried drugs which they profess to be potent and efficaceous at factastic prices." 26

7. Some physicians have argued that "... they would rather dispense than send prescriptions to shop assistants .... Since pharmacists are not there most of the time in the part-time shops ..."27

If these charges are true, it is a serious indictment on the integrity of many Nigerian pharmacists.

Looking at the other side of the issue, pharmacists in Nigeria may be engaged, to some extent, in the practice of medicine. In a Lagos University Survey of 1,000 consumers, 
30 percent acquired their last medication from a pharmacist without a physician's prescription. 28 Apparently, pharmacists prescribe drugs to their patrons in contravention of legal dictates and ethical standards. It is unfortunate that the study failed to identify what category of drugs this fraction of those questioned have obtained from their pharmacists. This survey, however, supports pharmacists' claims of professional competence, and their desire for better recognition of what their capabilities are. Apparently, the 30 percent who responded obtained relief from whatever pathologic problems they had, or they would have had to go to the physician. The syrvey also underscores the importance of the pharmacists in a developing country where the economy cannot affort the "Iuxury" of physician attention.

The physicians' charges against pharmacists - that pharmacists do not dispense the prescriptions sent to them, is also a serious issue. The implications are obvious. Pharmacists simply keep their pharmacies open and leave the premises to be manned by non-professionals. Physicians resent this practice and therefore stock their offices much as pharmacists would stock their pharmacies, and dispense their own preseriptions in direct competition with pharmacists. This raises the question of the integrity of the physicians too.

The possibility of prescribing and dispensing only drugs that are stocked exists; in essence, setting up a superficial formulary. It is not known whether or not, and 
in what rate if at all, physicians direct patients to pharmacists to obtain drugs that the physicians do not normally stock. It has been suggested however, that the lust for money may indeed force the physician to limit his prescribing habit only to drugs that are stocked whether or not they are the most appropriate for the disease diagnosed.

All this controversy revolves around a basic flaw in the Nigerian system:

1. The enforcement mechanism of laws enacted regarding the control of the professional practices of these groups is nothing but an illusion.

2. The laws enacted are not adequate for the control of these professions. 


\section{REFERENCES}

1U.S. Department of State, Office of Media Services, Bureau of Public Affairs, Background Notes, Nigeria, May 1975. p. 3
2U.S. Department of Health, Education and Welfare, ter for Health Statistics. Monthly Vital and tics, Advance Report, Final Mortality 1974. p. 2

30deral Ministry of Economic Development (Nigeria) Federal Office of Statistics. Third National Development Plan: (1975-1980): Health, 1974. p. 261

$$
\begin{aligned}
& \text { Ibid. p. } 263 \\
& { }^{5 \text { Ibid. }} \\
& { }^{6} \text { Ibid. p. } 261
\end{aligned}
$$

7Rhode Island Department of Health, Division of Professional Regulations. Comparison of Selected Health Professions. 1974 p. 2

$$
\begin{aligned}
& \text { 8IMS, Armaceutical Newsletter, September 1975, p. } 13 \\
& { }^{9} \text { IMS, Frld Drug Market Manual, part III } 1975,1: 14.2
\end{aligned}
$$

10 Federal Ministry of Information, Nigerian Handbooks 1963 Census $(1970)$ p. 26

11U.S. Department of Health, Education and Welfare, National Center for Health Statistics, Health Manpower: United States $(1965-1967), 14(1) \cdot$ p. 14

12IMS, opus cit. p. 14.1

${ }^{13}$ Federal Ministry of Economic Development, opus cit. p.264 
14 Ibid. p. 263

15Moses Bundukamara, "A comparative Study of the Practice of Pharmacy in Sierra Leone and the United States of America," Master of Science, Brooklyn College of Pharmacy, Long Island University, 1963. p. 59

16ernard Kouadvi, "African Traditional Pharmacopoeia," nal of Pharmacy and Pharmaceutical Sciences, Inc.,

in Pharmacist). June 7, 1972. 2: p. 401

17 Ibid.

18 Glenn Sonnedecker, "How Indian Materia Medica Sparked Therapy during America"s History, " Pharmacy Times, Nov. 1975 p. 52

${ }^{19}$ Ibid.

$7 y$ Times of Nigeria, Feb. 1, 1975, p. 18

21 IMS, Mrmaceutical Market Newsletter, Jan. 13, 1975

p. 14.5

${ }^{22}$ Ibid.

23 Bundukamara, opus cit. p. 50

24 Wilter Connelly, "The Pharmaceutical Potential in
Nigeria," Acal and Marketing Media, Oct. 1975 p. 20

Times of Nigeria, March 22, 1975, p. 7

Abid. 27Peter Ekwunife, "Employed Pharmacists Owning Shops
Personal Communication I," The Journal of Pharmacy, Nigeria
July/Sept. July/Sept. $1974,5(3)$, p. 39

28

IMS, Id Drug Market Manual, 1975, 1:14.5 
IV. EVOLUTION OF PHARMACEUTICAL LAWS AND PRACTICE, UNITED STATES AND NIGERIA

Just as the American criminal and tort laws are an outGrowth of the British Common Laws, so are the pharmaceutical laws enacted in Nigeria, in some ways an outgrowth of British pharmaceutical laws.

Nigeria enjoys the unique opportunity of not only emulating the British system, but emulating the American system as well in their judicial systems. West Africa ${ }^{1}$ reported that the present draft of the Nigerian Constitution-due to be ratified by a Nigerian Constituent Assembly in 1978 , will in theory, be similar in many ways to the United States Mstitution. Nigerian pharmaceutical laws have followed this pattern consistently.

\section{Pharmaceutical Laws in Nigeria}

Richard Z. Bailey was granted a license to open a pharmacy in Lagos in 1887. This, according to Egboh ${ }^{2}$ marked the entry into Nigeria of European Pharmacy. The law requiring examination and licensure of pharmacists was enacted in London in $1617^{3}$ and apparently was found fit for Nigeria, a country witnessing the entry of its first pharmacist.

Just as pharmacists served a period of apprenticeship under the physicians in the United States, the Nigerian 
"dispensers" of this time served under the supervision of the British Medical Officers.

cy Ordinance No. 8 of 1902 marked the beginning of pharmaceutical regulations in colonial Nigeria. It was designed to control the sale and distribution of drugs along the coastal areas of Nigeria. The term "dispensers" was discarded in the Act of 1923, when the term "druggist" was adopted. It was thought to be more prestigious and more reflective of the three year training course started at the newly constructed School of Pharmacy in Yaba, Lagos.

Ison and Pharmacy Act of 1927 provided for instruction of students for the "Dispenser's Certificate". Further studying would earn a Chemist and Druggist Diploma. Examinations were conducted by the Medical Supervisory Board.

Just as there was controversy over the professional status of pharmacists in Britain in the 1600 s and 1700s, there was also a delay in the recognition of pharmacists In Nigeria as professionals. Until 1969, remuneration of pharmacists was based on a classification of pharmacy at a sub-professional level. This was changed in 1969 on the recommendation of Professional Grading Team commissioned by Nigeria's Military Government.

In 1936, the Poison and Pharmacy Ordinance was enacted to bring pharmaceutical education in Nigeria in line with that of the United Kingdom. The syllabus and curricula of the Chomists' and Druggists' Diploma were standardized and a body known as the Pharmacy Board of Nigeria was created 
out of the representatives of the Nigerian Union of Pharmacists and the Association of Dispensers. This body is now known as the Pharmaceutical Society of Nigeria.

The 1936 Act also set up rules regarding the granting of licenses for the sale of patent and proprietary medicines, and also required the issuance of the Missionary Permits for dispensers who practice at missions. This Act reflects the level of sophistication of the Nigerian Pharmacy then and subsequent Acts are even more comprehensive, particularly in dealing with the expanding level of pharmaceutical service in Nigeris.

In 1946, there was an ammendment to the 1936 Ordinance repealing that requirement for the dispensers examination and Pongthening the establishment of the Pharmacy Board of Nigeria with the medical adviser as the Chairman. It also gave control and disciplinary powers over the practice of Tharmacy in Nigeria to the Board.

Following the 1946 Act came the Ordinance of October 1960 , the year of Nigerian Independence, which is termed the Poison

\section{Larmacy Act of 1960.}

What Egboh 4 termed the "magna carta" year of Nigerian pharmacy was in 1964 when the control of the profession was made the responsibility of the Pharmacy Board of Nigeria. The chairmanship of the Board was handed to the Chief Pharmacist of the Federation of Nigeria. The Pharmacy Act of 1964 lso made provisions for the determination of "what standards" of lnowledge and akills are expected" from prospective pharmacists. 
The year 1966 marked a turning point in Nigerian history as the Army took over the adminstration of the country. All actments heretofore called Ordinances are known as Decrees.

Most of what Nigeria now has as drug laws were enacted during some eleven years of military rule in Nigeria. The Indian Hemp Decree is perhaps the most stringent law on book in Nigeria. It was promulgated as a result of growing use of marijuana in the country. It decrees a twenty-one year jail, or death sentence for the possession or intent to distribute marijuana in Nigeria.

\section{phetamines Decree of 1968 was enacted to control} the use of amphetamines and amphetamine-like drugs in Nigeria. It also prohibits the use of and imposed strict penalty for the use of Lysergic Acid Diethylamine (ISD) and some other narcotic drugs.

The most comprehensive law enacted to control the Tharmaceutical industry in Nigeria is the Food and Drug Decree of 1974. This law reflects the trend in times as it deals for the first time ever with the control of manufacture of drugs. It also deals with various aspects of drug marketing which heretofore have not been dealt with. It deals with the inspection of the premises used for manufacturing drugs, and for the first time, there are provisions for the control of mufacture, distribution and marketing of devices.

\section{harmaceutical Laws in the United States}

Pharmaceutical laws were not enacted in the United States 
until the "Virginia Act for the regulation of the fees and accounts of the practicers of physics" 5 was passed in 1736 . At this time, the rates allowed those persons "who have studied physic in any university and taken any degree therein ..." were about twice as high as the fees allowed, "... surgeons, and apothecaries who have served apprenticeship for those trades..."6 For the protection of patrons against high fees charged by physicians and apothecaries at that time, the law stressed the need for complete disclosure of all drugs dispensed to the patients and also that moneys charged must reflect the quantities of drugs dispensed.

At about the same time, the Massachussetts Medical Society petitioned the legislature to "prohibit the sale of bad or adulterated drugs." Louisiana and North Carolina laws established the principle of licensure as prerequisite for the practice of pharmacy. In 1821, the Philadelphia College of Pharmacy was established as a protest against the encroachment of the medical profession in the profession of pharmacy. The first secretary of the American Pharmaceutical Association (APHA), John M. Maisch, suggested uniform state Tharmacy laws in 1868, and in 1900, pharmacist/lawyer James H. Beal vigorously promoted the passage of such laws.

As retail pharmacy expanded in the U.S., so did interest in drug manufacturing; and as new drugs were introduced into the American market, it became necessary to enact laws to curb the laissaz-faire attitudes among manufacturers and sellers of proprietary medicines. It was necessary to enact 
the and Drug Act of 1906 which was designed to enact penalties for certain types of misbranding and adulteration. 8 The disaster of the "elixir sulfanilamide" of 1937 which rilled at least 73 people, and the public demand for protection against the macrupulous practices of the pharmaceutical Industry, forced the congress to pass an even tougher legislation in 1938. This was the Food, Drug and Cosmetic Act Which imposed certain restrictions on the marketing of "new drugs". It also gave the Federal Government jurisdiction over medical devices and cosmetics. At the same time, congress passed an ammendment to the Federal Trade Commission Act in order to put effective control over false advertising of foods, drugs and cosmetics and over deceptive and unfair trade practices. 9

The thalidomide episode of congenital malformation reported in Europe and Canada in 1960 and 1961 precipitated the passage of the Kefauver-Harris Ammendment to the 1938 Law. This ammendment added the safety clause to the efficacy requirement for a new drug to be approved for marketing. It is perhaps the single most effective legislation passed in Congress to control the introduction of new drugs into the United States market. It curtailed, rather sharply, the Introduction of new drugs in the United States.

The Food and Drug Administration (FDA) imposes strict requrements on drug companies before drugs can be approved for marketing by the following:

1. requiring extensive testing to demonstrate safety 
and effectiveness.

2. requiring that companies continue to submit periodic reports on their drugg during marketing.

3. putting restrictions on advertising and other forms of promotion during marketing. 10

\section{af Significant Developments}

With the exception of the Foad and Drug Decree of 1974 , no other laws of significance have been enacted to control the practices of the drug manufacturers in Nigeria. It was not necessary to do so because of the absence of drug manufacturers in Nigeria. This parallels the situation in the United States during the colonial period under the United xingdom. Drugs generally were imported from Great Britain, and what was right for the U.K. at that time was considered right for her possessions.

However, since independence in 1960, several British companies, such as Glaxo Pharmaceuticals, May and Baker, started to do some manufacturing in Nigeria. During the mid1960s, some American companies started a small scale manufacturing in Nigeria, and it thus became necessary to set up guidelines. for the operation of their business as it impacts upon public health and safety.

The evolution of pharmaceutical practice and laws has taken similar paths in both countries. The pharmacy profession was subjected to intense pressure by the medical profession. Although Nigeria witnessed the entry of its first 
pharmacist nearly 100 years ago, it did not recognize pharmacy as a profession until 1969. Even now in the United States, the status of the pharmacists is under challenge. The United States pharmacist during the 1800 s became militant enough to break away from the shadows cast on them by the medical profession to form the first professional organization -The American Pharmaceutical Association.

In most cases, drug laws have eveolved in the United States throgh a national or international tragic experience from drug toxicity or adverse effects. In Nigeria, particularly before the military era, drug laws developed through evolutionary mens and through international influence. But since the beginning of military rule in 1966, drug laws have evolved through radical efforts of Nigerian legislature, and more importantly, from examples set by ther nations, particularly the United States. 


\section{REFERENCES}

${ }^{1}$ West Africa, June 28, 1976. p. 902

Andrew A. Egboh, History of Pharmacy in Nigeria 1887-1971. Literamed Publications Nigeria Ltd., 1972. p. 9

3Glenn Sonnedecker, Kremer's and Urdang's History of Pharmacy, J.B. Iippincott Company, 1963. p. 145

${ }^{4}$ Andrew A. Egboh, Textbook of Forensic Pharmacy in Nigeria, Iiteramed Publications Nigeria Ltd., 1974. p. vii

Ssanedecker, opus cit. p. 103

${ }^{6}$ Ibid. p. 100

${ }^{7}$ Ibid. p. 200

${ }^{8}$ Ibid. p. 201

${ }^{9}$ Ibid. p. 47

10 M.C. Smith, Principles of Pharmaceutical Marketing, 2nd edition. Lea and Febiger (Philadelphia), 1975. p. 395 


\section{GOVERNMENT CONTROL}

\section{3n of Selected Aspects of United States and}

Prarmaceutical Laws.

As consumption of drugs rises each year in Nigeria, and as the nation's economy develops in massive proportions (per capita comsumption of drug is still about $\$ 1.00$ compared to $\$ 30.00$ in the United States in $1975^{1}$ and the Nigerian Gross National Product (GNP) was about $\$ 27$ billion $^{2}$ compared to United States $\$ 1,400$ billion in 1975), more and more pharmaceutical companies are finding their way into the Nigerian market. And as the scramble for the Nigerian market continues, the Nigerian Government is imposing more restrictions on business activities of foreign companies in Nigeria.

The Indigenization Decree Ammendment of $1977^{3}$ classified all business activities into three categories:

1. Schedule Is Those business which are exclusively reserved to Nigerians.

2. Schedule II. Those business which allow 40 percent foreign participation and

3. Schedule III, Those business that allow 60 percent foreign participation.

The pharmaceutical industry is grouped in Schedule III.

In the United States, several government agencies are given the statutory authority to control the distribution of 
drugs. Chief among these is the Food and Drug Administration (FDA) which controls the marketing and promotion of prescription drugs. It also shares in the responsibility for the control of the promotion of over-the-counter drugs with the Federal Trade Commission (FTC). 4 The FDA inspects manufacturing facilities, reviews and approves or denies the clinical testing of arugs prior to marketing; limits the therapeutic claims for products and monitors advertising. Recently the FDA embarked on a major scientific examination of the medical credentials of prescription drugs on the market.5 0ther Bevernment agencies involved in the control of the distribution of drugs are: The Drug Enforcement Administration (DEA) which is responsible for control of drugs with misuse and abuse potential, and the Division of Biologic Standards (DBS) which controls the distribution of Biologics.

In Nigeria, there is only one agency designated by the military government which controls the activities of the drug industry in areas of manufacturing, distribution, promotion and advertising. The agency is the Food and Drug Advisory Council (FDAC). Its function is to formulate guidelines in the following areas:

(a) Determination of adulterants

(b) Packaging, labelling specifications and sale

(c) Preventing the consumers and users from being misled by manufactures as to the value of the ingredients

(d) Laying down standards to be attained by articles

(e) Importation 
(f) Uanufacture, preparing, packing, storing and testing of articles

(g) Maintenance of books and records as prescribed

(h) Application and issue of certificates to qualified manufacturers and conditions required of the premises where manufacturing will be undertaken

(i) Acquisitions of test batches of drugs manufactured to ascertain their suitability and paying the prescribed fees

(j) Mode of sampling reporting

(k) Exemption of certain materials from the provisions of the Act

(1) Prescription of the forms to be used

(m) Conducting analysis and prescribing fees for such analysis

(n) Distribution of samples of any drug

(o) Ammendments of the schedules as may be necessary

(p) Prescription of other things for the execution of this Act.

These functions are shared among other sub-agencies under the FDAC. The sub-agencies are as follows: 6

1. Federal Manufacturing Laboratory

2. The Federal Medical Stores, Oshodi

3. The Kano Airport

4. Pharmaceutical Registry and

5. The Inspectorate Unit. 
The Federal Manufacturing Laboratory does not presently unufacture drugs as the name implies, but there is a plan to extend the existing laboratories to increase the production of simple and cheap drugs for use in government hospitals. The FDAC is headed by the Chief Pharmacist of the Federation who is responsible to the Minister/Commissioner for Health.

Several areas of comparison exist between the Drug Laws of Nigeria and the United States and they will be explored in detail under the following titles, Product Standards, Pricing, Distribution and Restrictive Sale and Promotion and Advertising. Comparison will be made between the two systems and major differences will be identified.

\section{luct Standards}

The United States, through the Food and Drug Administration (FDA), establishes standards of safety and efficacy through a battery of pre-marketing testing which almost entirely eliminates the possibility of marketing products which are unsafe for human consumption. Pre-marketing testing is done on pnimals as required by the provisions of the "Notice of Claimed Investigation New Drug (IND). Pre-marketing testing on humans is done as required by the provisions of the New Drug Application (NDA).

Before the application for the IND is filed with the $F D A$, it is assumed that all details about the pharmacology, chemistry, biology, etc. of the new drug product, have been 
known. The next step is to apply this knowledge in clinical testing on human beings.

The New Drug Application requirement is in three phases: Phase Is

A period of human pharmacology, when investigations are designed to indicate toxicity, dosage, absorption, excretion and fate in the body.

Phase II:

A period of limited trial of the drug in patients with the disorder the drug is designed to treat.

\section{Phase III:}

Large scale trial on patients with the specific disorder. Arnow 7 has estimated that it takes at least sever-and-a-half years (the Pharmaceutical Manufacturers Association - PMA has said 10 years) from the period of gestation of a potential new drug to final approval of the drug for marketing by the FDA. If the new drug is an antibiotic, the FDA laboratory assays it to determine that it has the required potency and safety and that it meets certain other standards of quality. Each batch of antibiotic produced must be so certified. 8

Before the 1961 thalidomide disaster in parts of Europe and Canada, only a safety requirement was imposed on new drugs in the United States. After the disaster, efficacy requirement was added through the provisions of the Kefauver-Harris Ammendment of 1962. This ammendment also, for the first time provided a definition for "new drugs". 
In some instances, the Food, Drug and Cosmetic Act of 1938 is similar to the Nigerian Food and Drug Decree of 1974 which preants all drug laws enacted in Nigeria before 1974. Paragraph 7 of the Decree reads as follows:

No person shall manufacture for sale, any drug specified in schedule 4----without obtaining a cortificate from the commissioner that the premises in which the drug is intended to be manufactured and the conditions by and under which the manufacture is to be carried on are---suitable for ensuring that the drug will be safe for use. 9

Materials listed in schedule 4 are as follows:

Liver Extract in all forms

Insulin in all forms

Anterior pituitary extracts

Radioactive isotopes

Living vaccines for oral or prenteral use

Drugs prepared from micro-organisms or viruses, for patenteral use

Sera and Drugs analogous thereto, for parenteral use Antibiotics for parenteral use.

As seen in the above list, some of them are biologicals, some are biological extracts, one is a radioactive isotopes and some are antibiotics. The emphasis in the above regulation is on the "... premises in which the drug is intended to be manufactured....". It can be noted that the safety of the drug as regards its toxicity has not been mentioned. The requirement in the above regulation has been modified in paragraph $7(2)$ of the Decree which will be discussed below. 
The mplication of the above law is that once the premises in which the drugs are intended to be manufactured are certified by the commissioner, the drug manufactured therein must be gafe. Safe in the sense that the drugs do not contain "dirt or filth" or any substance that would make them injurious to health".10 The toxicity of any drugs sold by the multinational drug companies is not at this time in question. Their integrity is not being impugned; their experience in the United States is enough to prevent any reoccurrence of the "Blixir Sulfanilamide" disaster of 1936. However, the local mufacturers, particularly the indigenous Nigerian drug companies, operate within the same law. This is where there could be potential problems.

Raragraph $7(2)$ of the Food and Drug Decree states as

\section{follows:}

No person shall sell any drug specified in schedule 5 of this decree without first obtaining in accordance with the regulations a certificate of the commissioner that the batch from which the drug was taken is safe for use.1I

Drugs in schedule 5 are as follows:

wophenamine

Dichlorophenarmine Hydrochloride

N hrsphenarmine

Oxophenarmine Hydrochloride

Sensitivity disc and Tablets

S Marsphenamine

These are heavy metal compounds used as anti-infectives or 
perhaps as anti-amebics. These drugs are not used extensively in Nigeria. In fact, they are not used much in the United States either. However, they are subject to as much safety requerements as are imposed on the manufacture of antibiotics in the United States. This might be due in part to the heavy toxicity associated with this class of drugs.

It must be noted that this is the only group of drugs subjected to such a requirement in Nigeria. This is in contrast to the United States law which only restricts such requirement to antibiotics due to possibility of variations in the active ingredients from batch to batch during manuPacture. In Nigeria, antibiotics are not subject to such a requirement.

The implication of this law is that all other drugs can be inufactured in Nigeria without a proof of batch to batch certification. Antibiotics manufactured by United States empanies outside the United States are thus, not subjected to this requirement as long as the sale of such antibiotic in Nigeria would not be a contravention of the law of the country of manufacture.

Fragraph 5 of the Food and Drug Decree states as follows:

No person shall label, package, treat, process, seli or advertise any food, drug ... in any manner that is false or misleading or is likely to create a wrong impression as to its quality, character and value, composition, merit or safety. 12 The provisions of this paragraph may be subject to different kinds of Interpretations depending on each individuals' 
interest. Manufacturers may claim exemptions from the requirements of the paragraph because of their apparent exclusion from the provisions of the decree. The government on the other hand, can claim that the words "quality, character, and value and merit" when taken together and read in the appropriate context, mean "efficacy" or "effectiveness". This decree is analogous in context to the Federal Food, Drug osmetics Act of the United States prior to 1962 when only a proof of safety of drugs was the only requirement.

\section{the Food and Drug Decree and the FDA Regulations}

The Food and Drug Administration regulations have a significant impact on the activities of the Drug companies in the United States, particularly in the periods after the 1962 Kefauver-Harris Ammendments. Although the decline of new drug introductions and in the new drug approval rate in the United States cannot singularly attributed to the effects of the ummendments, it goes a long way in explaining such a aceline. Table 4 shows the decline in the introduction of single new entity drugs in the United States from 52 in 1957 to 15 in 1975. Table 5 shows a decline in number of total Ppproved NDAs in comparison to number of INDs submitted.

In 1966, seven hundred and fourteen INDs were submitted 147 of them reached the NDA stages and only 40 of them were approved -- an approval rate of approximately 21 percent. In 1970, one thousand one hundred and twenty INDs were submitted, only 92 of them went to the NDA stages, and only 
TABLE 4

Year

1957

1958

1959

1960

1961

1962

1963

1964

1965

1966

1967

1968

1969

1970

1971

1972

1973

1974

1975
No. of Single New Entity

52

47

65

50

45

24

16

17

25

13

25

12

9

16

14

10

17

18

15

Source: Pharmaceutical Manufacturers Association, Prescription Drug Industry: Factbook, 1976, p. 11 
TABLE 5

DPROVAL RATES IN THE U.S. (1966, 1970-1975)

\begin{tabular}{lrrrr} 
YEAR & $\begin{array}{r}\text { TOTAL NO. OF } \\
\text { INDS }\end{array}$ & $\begin{array}{c}\text { TOTAL NO. OF } \\
\text { NDAS }\end{array}$ & $\begin{array}{c}\text { TOTAL NO. OF } \\
\text { APPROVALS }\end{array}$ & $\begin{array}{c}\text { PERCENT* } \\
\text { APPROVED }\end{array}$ \\
\hline 1966 & 714 & 147 & 40 & 6 \\
1970 & 1120 & 92 & 51 & 5 \\
1971 & 938 & 99 & 62 & 7 \\
1972 & 976 & 297 & 57 & 6 \\
1973 & 913 & 146 & 50 & 5 \\
1974 & 842 & 106 & 85 & 10 \\
1975 & 818 & 132 & 71 & 9
\end{tabular}

Average approval rate beginning from 1970 is 7 percent. Average approval rate for the three periods requested in this otudy between 1973 and 1975 is 8 percent.

"Percentage is calculated based on total number of INDs and total number of approvals.

Source: FDA Annual Reports and FDA unpublished data. 
40 of them were approved -- a rate of approximately four percent.. In 1975, eight hundred and eighteen applications were submitted, 132 of them reached the NDA stages and only 71 of them were upproved -- a rate of 8 percent.

There is also a considerable decline in number of firms operating in the United States from 127 in 1957 to 48 in

1968.13 It has been estimated that the existing multinational companies will themselves grow and the increasing complexity of research and the demand for higher standards of safety and efficiency will raise the costs and encourage further amalgamations and takeovers. "By 1990 worldwide pharmaceutical research production and marketing will mostly be in the hands of some one or two dozen companies. About half of these will have originated from the United States."14

The present conditions in most developing countries and particularly in Nigeria which is the dominant force in Black Arica, make it a fertile ground for pharmaceutical companies of many nations,

The Hathi Committee ${ }^{15}$ has drawn up a list of essential drugs for the basic needs of India. The list contains a total of 116 drugs which are considered to be adequate for the medicinal needs of India. This view is shared by Mayler in his report published in the World Health Organizations ipnthly Chronicle as follows:

In many developing countries, the lack of national Thg policies allows foreign pharmaceutical firms to influence the market demand to a considerable extent and to control the transfer of pharmaceutical 
tenlmology when local production is undertaken by their subsidiaries or under licensing agreements. thrthermore, the regulations of the supply or prices of raw materials greatly influences the iocal production of finished pharmaceutical products. Thus many developing countries remain dependent on foreign interests and spend a high proportion of their limited health resources on imported finished products or raw materials for local production of drugs, many of which are not suited to their real health needs.16

It is not known how many drugs are sold in Nigeria, but if such a study were conducted in Nigeria, the result would probably be similar to India's. It is estimated that only a small proportion of the order of one or two percent of the arugs marketed in developing countries would be sufficient to cover basic pharmaceutical needs.17 There are obviously much more than 116 drugs on the Nigerian market.

The price paid for these drugs is the next topic of discussion.

\section{Pricing}

Seyeral laws have been enacted with the sole aim of preventing indiscriminate pricing procedures on the market. 1. Antitrust Act of 1890 is the principal act that deals with "price fixing". Others include the clayton Act of 1914 which outlaws price discrimination, tying contracts, exlusive dealings and etc.; the Federal Trade Commission Act of 1914 which was established to enforce the provisions of the Clavton Act; and the Robinson-Patman Act of 1935 which prohibits the granting of different prices to different buyers of commodities of like grade and quality, where the 
effect of such practice is a reduction in competition.

Gomerally, United States wholesalers' and manufacturers' prices are not controlled. At retail level however, some control exists, particularly, through cost control in the state medicaid programs.18 In some European countries, a product cannot be registered if the price is unreasonable. France and Italy have formally frozen prices on pharmaceutical products. Others have ordered a price roll-back. Economic considerations play a major role in the registration of drug products in many Europena countries. For example, in several of the Furopean countries, a product cannot be registered if the price is unreasonable. This is expected to be a major consideration in the United States When the National Health Insurance becomes a reality.

In Nigeria, the consideration for registration of drugs is bastcally safety. Economic considerations are of low priority except when the government initiates competitive bidding for drug sales among drug companies.

The Price Control Board has not been very effective in dealing with rising prices of commodities in Nigeria.19 The government has, however, taken reactionary steps during atreme price hikes by the various industries, particularly, the food Andustry. Roll-backs are recommended where prices are found to be unjustifiably high. So far in the pharmaceutical industry, no price controls have been ordered and it is highly unlikely that there will be significant controls on the pharmaceutical industry at some future time. 
In Nigeria, as in many other places, the pricing of drugs is affected by the method of buying, which does in turn, suggest resale values. The process commonly used by the Nigerian Army, which is a major drug purchaser, is a competitive bidding system called "tender". Using its monopsony power, the government can and does set price limits on drug products in the Nigerian drug market. Drugs obtained through tender are given duty-free certificates and their resale prices are often much cheaper, comparatively. 20

Some multinational companies have taken advantage of lack of adequate price control regulations in the developing countries where prices of many drugs have increased by more than 100 percent in the last few years. 21

The method of transfer-pricing adopted by some multinational drug companies is another problem which developing nations such as Nigeria have to contend with. In Colombia, South America, certain tranquilizers were sold at 4,000 to 4500 percent higher than alternative world market prices. In Iran in 1960s, intermediate bulk chemicals sold at between 38 and 1000 percent higher than in developed nations where the bulk chemicals were manufactured. The price of the intermediate chemical would obviously have an effect on the price of desage forms.

\section{ion and Restrictive Sale}

The method of distribution and the control on drug 
products depend mainly on what type of drug is under consideration. Three classes of drugs will be discussed:

\section{counter (OTC) Drugs}

These are drugs that are made available directly to the purchaser without prescription. Controls imposed on such drugs are similar to those imposed on the distribution of commodities under the provisions of the Uniform Commercial Code (UCC). The potential danger posed by this class of drugs has been minimized by the "7-point label" required on all orc drugs in the United States. The 7-point label is as sollows:

1. the name of the product.

2. the name and address of the manufacturer, packer, or distributor.

3. the net contents of the package.

4. the established name of all active ingredients and quality of other ingredients whether active or not.

5. the name of any habit-forming drug contained in the preparation.

6. the cautions and warnings needed for the protection of the user.

7. adequate direction for safe and effective use. 22 OTC drugs are available through many outlets where commodities are sold. They are available at supermarkets, pharmacies and etc. However, some OTC products are made available to the public exclusively through pharmacies. This group of drugs are also known as OTC ethicals". They are not promoted to the public. 23 
The distribution of OTC drugs in Nigeria is through various convenient outlets such as supermarkets, patent medicine stores, gound-trucks and, of course, pharmacies. Patent medicine stores and sound trucks are similar to their practice except that sound trucks are mobile forms of patent stores. The sound trucks usually go from one place to the other selling drugs. The patent medicine stores, according to Egboh, 24 have out-numbered pharmacies more than ten-fold; and they are engaged in selling all kinds of drugs including those which are avallable only under a doctor's prescription.

There are no regulations controlling the sale of OTC drugs in Nigeria. No provision is made in the Nigerian Food 1 Drug Decree for thecontrol of the distribution of any of these drugs, and for that matter, there is no provision made about this class of drugs in any of the Nigerian laws. It is assumed, however, that manufacturers, particularly, foreign manufacturers, will conform to the requirements of the regulation, of their home countries to control the sale of over-the-counter drugs.

\section{ription Drugs}

The distribution of prescription drugs is carried out Harough pharmacies and physician offices. But as Mr. Egboh pointed out, they are being sold over-the-counter by Nigerian patent medicine stores. 25

The 1951 Durham/Humphrey Ammendment to the Food, Drug and Cosmetic Act categorizes the kinds of drugs that may be dis- 
pensed by the pharmacist only on the prescription "of a practitioner licensed by law to administer such drugs". such drugs must bear the legend - "Cautions Federal Law prohibits dispensing without prescription." Hence the term, "Iegend drug" in reference to this class of drugs.

other requirements of this ammendment are as follows:

1. It prohibits refilling of such prescription without expressed authorization of the prescribing physician.

2. It provides for oral or telephone prescriptions of legend drugs.

3. It provides for oral or telephone authorization of refills of legend drug prescriptions. 26

In Nigeria, through the provisions of the Dangerous Drug Act, the pharmacist, physician, dentist, and the veterinarian have the authority to handle prescription drugs which are called "poisons" and classified into six parts:

I. Crude dangerous drugs such as raw opium, coca leaves and Indian Hemp (Marijuana).

II. Prepared opium.

III. Medicinal Dangerous Drugs (with the exception of Cocaine and marijuana, all drugs listed in this part are derivatives of opium).

IV. Bxternal Trade in dangerous drugs.

V. Trade in new Drugs.

VI. General.

Rpstrictions ordered on items in Parts I and II is as follows: (a) No one other than a registered pharmacist shall 
sell poisons included in parts I and II.27

on part III, it says that these drugs can only be obtained -

(a) On signed order by qualified persons,

(b) on prescription by those who are qualified by this Act (doctors, dentists and veterinarians).

on part IV (trade in new drugs), it says as follows:

(a) No person shall sell or import poisons included in part IV unless he or she is a registered pharmacist,

or (b) a person holding a license to import part IV poisons. 28

Parts $V$ and VI are in essence a repetition of the regulations in parts $I$ and IV.

It is not known how these classifications are arrived at. But, with them are a list of do's and don'ts which in the final analysis are saying exactly what the United States m/Humphrey ammendment is saying, viz: that certain drugs cannot be dispensed to the public by the pharmacist unless by prescription written by qualified individuals who have been certified to do so.

What these regulations prohibit, in brief, is the sale of fangerous drugs such as morphine, heroin and marijuana (particularly those drugs which the United States would classify as schedule (II drugs), unless they are on prescription written and signed by authorized individuals. Obviously, marifuana and heroin are out of place in this list. It is certainly not the intention of the Nigerian legislators to include marijuana in the category of drugs which can be 
dispensed by the pharmacist on prescription only.* The effects of the Durham/humphrey ammendments on the States is two-fold. Apart from reducing the incidence of illicit wrafic in drugs, particularly those with abuse and misuse potential, it sets limits on the distribution of these drugs through legitimate channels by limiting the number of allowable prescription refills and requiring more extensive recordreeping. 29

Pharmacy Practice Act is not as clear in its focus as the ham/Humphrey Ammendment. Its effects on the pharmaceutical Industry is not quite apparent. However, it can be concluded from discussions in Chapter IV, that this law is not being adequately observed.

\section{trolled Drugs}

As indicated earlier, legal restrictions on the distribution of a drug depends to a large extent, on the characteristics of the drug in question. Controlled Substances are perhaps the most restricted commodities in any country, whether Ngeria or the United States.

There have been massive efforts to control Narcotics and other angerous drugs through treaties, protocols and international conventions. The emphasis has been on the restriction of the production of opium to medical and scientific needs.

The provisions of the Indian Hemp Decree supports this Pontention. 
The United States has participated in all conventions, treaties and protocols since 1909.

Nigeria participated in the convention of 1961 (Single Convention on Narcotic Drugs) for the first time as an indepandent nation. 30 At this convetion it was decided that nations which at that time "permitted quasi-medical use of opium ... and coca leaves", shall take, within a period of 25 years (beginning from 1961), steps to eliminate such practices. 31

Three Acts stand prominent in Nigeria, that deal with the manufacture, sale and distribution of narcotic drugs. These are as follows:

1. The Dangerous Drug Act

2. Toe Controlled Substances Act and

3. The Food and Drug Decree.

Ton and Pharmacy Act provides guidelines for the pharmacists in the process of carrying out his duties within the boundaries of the law.

\section{yous Drug Acts (DDA)}

This Act lists some 100 drugs which are subject to restrictions in the areas of importation, exportation, sale and dstribution.

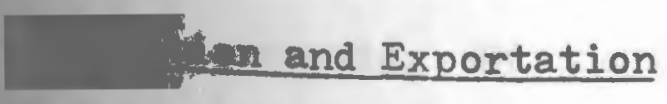

Import Certificate or the Export Authorization must be obtained from the Comptroller of Customs before such import or export can be allowed. 


\section{Distribution}

Since the sale and distribution of drugs are mostly effected by the pharmacist, the control of sach is under guidelines set by the Poisons and Pharmacy Act. Under its provisions, a pharmacist must:

1. Ensure that a precription for controlled drugs is genuine.

2. Not dispense the drug more than once unless it is so specified by the prescribing physician.

3. Make a record of the sale and keep such a record for at least two years.

Among other restrictions imposed on the physicians as regards the prescription of controlled drugs, he (the physician)

"shall not be authorized to prescribe a medictnal dangerous drug for his or her own use" .32

But for this restriction on the physician, there is a thiking similarity between the provisions of the Nigerian Arous Drug Act and the United States Comprehensive Drug Ievention and Control Act of 1970. While some states prohibit such practice, the general rule in the U.S. is that a physician may write prescription for schedule II drug for his personal use provided he is doing so "in good faith".33

The DDA covers drugs such as, morphine and its derivatives; meperidine and related substances and methadone and related compounds. By the United States classification, most of these drugs belong to Schedule II.

\section{Ted Substance Act of 1968 (CSA)}

This decree was enacted in 1968 to deal specifically, 
with the importation, sale and distribution of amphetamine and amphetamine-containing products. However, it was repealed by the enactment of the Food and Drug Decree of 1974.

\section{Drug Decree of 1924}

The Food and Drug Decree (FDD) replaces many of the drug laws in Nigeria. Controlled Substances are dealt with under the provision of paragraph 3 of the decree which says

Except as authorized by the regulation, no person shall import into Nigeria or export therefrom, manufacture, sell, distribute or cause to be distributed (whether as samples or otherwise) any of the drugs specified in schedule II of this decree. 34

Schedule II drugs are those which are classified under schedule I or II of the Controlled Substances Act of the United States. Part A of Schedule II of the decree consists of the lollowing:

DET, DMHP, DMT, ISD, Psilocybin, STP, DOM and Tetrahydrocannabinols. It also includes the Amphetamines and derivatives, amphetamine-like drugs, and all preparations containing some quantity of amphetamine.

But for the inclusion of the amphetamines in this -section the list could have been referred to as an extract of the United States schedule I drugs, with some minor addition.

Part $B$ of the devree deals with the following class of drugs:

1. Sedatives and hypnotics - barbiturates

2. Non-barbiturate sedatives and hypnotics - glutethimide nethyprylon, etc.

3. Skeletal Muscle Relaxants - Meprobamate 
4. Tranquilizers e.g. the phenothiazines

5. Central Nervous System Stimulants - Caffeine

6. Mdrenergics e.g. Ephedrine and its salts

7. Artificial Sweeteners such as Cyclamtes*

The list includes other drugs such as cobalt preparations, mallic tin and its compounds, potent antibiotics such as chloramphenicol and its preparations and many others.

The controls on these drugs are similar to the controls imposed on drugs listed under the Poisons and Pharmacy Act.

The classification seen above consists of drugs that can be classified under Schedule I through $V$ of the United States CSA depending upon the potential for misuse and abuse of the particular drug in question. Many of the drugs listed on the other hand, are not subject to the control of the Mled Substances Act of the United States, for example, cyclamates have been banned in the United States; Ephedrine and its salts are not under the provisions of the CSA, and caffeine is widely sold over-the-counter.

In most of the drug laws, there appears to be an overlap in the restrictions imposed on importation, exportation. manufacture, distribution and etc. of all kinds of drugs with the exception of OTC drugs which apparently are not subject to any kinds of restrictions. More confusing is the attempt to classify the controlled drugs and separate them from non-

"See Appendix for complete list 
cutrolled, legend drugs. For example, the idea behind the splitting of Part A and Part B of schedule II of the FDD into two groups and subjecting these two groups into identieal legal restrictions is not clearly understood. It is known that Part $A$ is a list of highly abused drugs which are grouped into schedule I of the United States CSA. To subject this group of drugs to the same standards required of drugs in Part $B$ is inappropriate.

It can be seen that there are only minor differences between the CSA of the United States and the provisions of the Nigerian FDD and the other two Acts in the control of the distribution of narcotics in both countries. It appears that the Nigerian law is, in part, an extract from the United States law with only minor additions which, when taken together make the Nigerian law on controlled drugs rather more conservative and more stringent.

Mr. J. Pink" has said that the "escalation of drug legislation by a "leap-frogging motion" probably arises from countries seeing protections enjoyed by other countries (and) olamouring for even better protection in their own (countries) without recognizing the debit effects that go with them." 35 The "debit effects" in this case can be hypothesized:

1. It is not certain that Nigeria has adequate resources (manpower and financial capital) to monitor and establish an effective control of the industry with 
the result that some of the laws passed are never enforced.

2. Some of the laws are not appropriate to the prevalling conditions in Nigeria, particularly in cases such as the restrictions imposed on distribution of caffeine and the adrenergics which in many cases are sold over-the-counter in the United States.

3. There is less incidence of drug abuse and misuse in Nigeria than there is in the United States and such controls are unnecessary.

\section{tion and Advertising}

With the exception of the law that specifies that detail men have to be qualified in pharmacy, not legislations have been passed to control the promotion of drugs in Nigeria. However, the advertisement of drugs is controlled through the provisions of paragraph 3 of the Food and Drug Decree. It says Save as otherwise provided, no person shall.

(a) advertise to the general public any food, cosmetic, or device as a treatment, preventative or cure for any of the diseases, disorders, or abnormal physical states specified in schedule I to this decree. OR

(b) sell any food, drug ... that is represented on the label or is advertised to the general public as a treatment ... for any of diseases ... specified in schedule I.*

The blanket prohibition on the advertisement of drugs used in the treatment of the diseases. listed in schedule I 
is rather broad. It implies, for example, that drugs used in the treatment of common colds can be advertised provided they do not contain antihistaminics, which incidentally, are also used in the treatment of hay fever. Neo-synephrine(R), which may be used in combination with other drugs for the treatment of bronchial asthma, cannot by implication, be wertised. Rheumatic Arthritis is another ailment listed in cosedule I. Obviously, it is not the intention of the legislature to prohibit the advertisement of aspirin and aspirincontaining drugs which are widely used in the treatment of rheumatic arthritis. The inclusion of gastrointestinal vicers in the list may also be questioned since there is a vide application of antacids in the management of this disease. Nany of the drugs in the categories mentioned are widely sold over-the-counter in Nigeria.

Alternatively, it is not clear why many diseases are areluded from the list. Malaria, emphysema, bronchitis, allergic diseases and many others are not listed. It is inglied that drugs used in the management of these diseases can be ndvertised.

There are certainly many loopholes in this particular part of the Food and Drug Decree which make it very difficult to understand and difficult to enforce. The effect of this on the munfacturers can be theorized.

The Nigerian law against misbranding is analogous to the United States law of 1906 which prohibits adulteration and misbranding. Paragraph 5 of the FDD states that, 
No person shall:-

labe , package, treat, process, sell or advertise any lood, drug, cosmetic or device in a manner that is false or is likely to create a wrong thpression as to its quality, character, value. composition merit or safety.

It is apparent from the typical drug advertisement seen in the course of the research that manufacturers may be circumventing the provisions of this law by failing to give proper directions for the use of the drugs just as they did after the enactment of the Federal Pure Food and Drug Law of 1906.36 Roche's advertisement of Valium $(R)$ in the United States and in Nigeria is a typical example of the activities of the drug companies. In the Nigerian advertisement, Roche promotes only all the attributes of the drug and merely refers readers to the packing slip for more information. In the United States the same company not only wrote out information concerning the attributes of the drug, but also included the c crindications, wamings, precautions, dosage, management of overdose and how the drug is supplied. All these are Wuired by the United States FDA and the FTC. Moreover, the advertising contains reference to Roche's complete product information guide for more information.

Another example is the Merck, Sharp and Dohme's advertisement of Aldomet $(R)$ in both countries. In the United States paper, there is practically complete prescribing information; but in Nigeria, the information made available is sparse and incomplete.

Even in the United Kingdom, which in most instances, 
serve as a model for marketing activities in Nigeria, the United Nations Conference on Trade and Development reported thats

"... recent investigations ... showed that several TNCs (Transnational drug companies) were selling everal hundred drugs which had been withdrawn from the American market by the Food and Drug administration as "lacking evidence of effectiveness." 37

An example of this is seen in the case of an American drug company which makes a brand of chloramphenicols

The manufacturer has had difficulties with the United States authorities for years over the undesirable side effects of the drug and has paid over a million dollars in damages for failing to warn of these effects. Yet it continues to promote this drug heavily in the United States and other countries; in the U.S., however, it is required to warn against six conditions in which the drug should not be used, in the Federal Republic of Germany and Australia only one, and in several developing countries, none at all. 38

Industries in Nigeria have enjoyed major concessions from the government in form of incentives such as tax relief, low tariff rates for imported products, etc. But recently, several changes have been made and are being made which threaten those incentives in some cases or eliminate them completely in others. The pharmaceutical industry is not very threatened at this time, but their incentives have been drastheally reduced.

The marketing of drugs is controlled by several government agencies in the United States, on the contrary such a vesponsibility is charged to one agency in Nigeria called the Food and Drug Advisory Council ctreated only in 1974. The Nigerian pharmaceutical law, particularly as 
exemplified by the provisions of the Food and Drug Decree, etreates an illusion that there is adequate control over the activities of the drug industry when in fact, it is full of loopholes that provide incentives for unscrupulous marketing practices.

Although there is no evidence of widespread illegal Practice by the drug companies in Nigeria, conditions are condusive for such practice, particularly when competition becomes more vigorous. Such evidence has been found in other Meloping countries where drug laws are as relaxed as they are in Nigeria. Prices have been found to be excessively high in countries of South America where conditions are similar to Nigeria's.

In many cases, Nigeria's drug laws are subject to various interpretations depending on individual s interests and in some instances, the laws are ahead of the United States drug laws in level of stringency.

It has been found that Nigerian drug laws in some instances are analogous to the United States laws in the late 1930s when conditions were similar to the conditions in Nigeria at present.

Rood and Drug Decree's classification of drugs into phedules is one of the most confusing aspects of the law. It has different unrelated criteria for each group of drugs or medical supplies. In this case, the United States laws are much clearer and more logical in sequence.

In general, however, the laws in both countries are 
similar in context, and the same trend in escalation of pharmaceutical laws by a "leap-frogging motion" in other countries, particularly in the United States, is currently in motion in Nigeria and catching up to the United States is a matter of time. 


\section{REFERENCES}

1. instry: Factbook, 1976. Published by the PMA, 1976

2James Flannigan, "Nigeria, Where the Action Really Is," Forbes, Dec. 1, 1976 p.51

lest Africa, Jan. 31, 1977. p. 200

${ }^{4}$ Mickey C. Smith, Principles of Pharmaceutical Marketing, 2nd edition, Lea and Febiger (Philadelphia) 1975. p. 395

\section{SIbid.}

6 Andrew A. Egboh, History of Pharmacy in Nigeria 18871971. Literamed Nigerian Publications Itd. p. 24

7I. Earle Arnow, Health in a Bottle: Searching for the that Help, J.B. Lippincott (Philadelphia), 1970. p. 41

8)artin M. Rosner, "U.S. Pharmacy and European Drug Gislations," Journal of American Pharmaceutical Association, NS 12 No. 12. Dec. 1972. p. 627

Inand Drug Decree No. 35, 1974 (Nigeria), paragraph 7

10 Andrew A. Egboh, Textbook of Forensic Pharmacy in Nigeria, Literamed Publications Nigeria Ltd. 1974. p. 48

11 ind and Drug Decree, opus cit. paragraph 5.

${ }^{12}$ Ibid.

${ }^{13}$ Pharmaceutical Manufacturers Association, opus cit.

14 United Nations Conference on Trade and Development (JNCTAD). Major Issues in Transfer of Technology to Developing Geuntries: A Case Study of the Pharmaceutical Industry. tola $0.6 / 4$. p. 16 
15Ibid. p. vii

16 H. Mayler, "Report on Transfer of Technology, " Pharaticel Journal (Iondon), July 26, 1974 p. 59.

${ }^{17}$ Ibid.

${ }^{16}$ Rosner, opus cit. p. 628

19 U.S. Department of Commerce, Bureau of International fommerce, "Selling in Nigeria," Overseas Business Report LR 730-41, p. 5

${ }^{20}$ Lai, opayemi, "Drug Distribution in a Developing Countrys Nigeria," Journal of Medical and Pharmaceutical Marketing 4(6) Sept.-0ct. 1976. p. 309.

${ }^{21}$ UNCTAD, opus cit. p. 40

Y.T. Eugene L. Kaluzny, Pharmacy Law Digest, Douglas McKay, Inc., 1976-1977. p. 166.08.

${ }^{23}$ Mickey C. Smith and David A. Knapp, Pharmacy, Drugs and Aical Care, Williams and Wilkins (Baltimore). 1972, p.251

24 Andrew A. Egboh, "Pharmacy Practice," Pharmaceutical Journal (Nigeria) Jan/April 1973. p. 30

25Egboh, Text Book of Forensic Pharmacy in Nigeria, opus cit. p. 17

${ }^{26}$ Kaluzny, opus cit. 166.03

P"Egboh, opus cit.

${ }^{28}$ Ibid. p. 83

29M.C. Smith, opus cit. p.392 
30William Pettit, Manual of Pharmaceutical Law, Macmillan Company (New York), Collier-Macmillan Ltd. (Iondon) 1962. p. 50

${ }^{31}$ Ibid. p. 52

$32_{\text {Egboh, opus cit. p. } 75}$

33Kaluzny, opus cit. p. 56

bod and Drug Decree (Nigeria) opus_cit. par. 3

$35 \mathrm{~J}$. Pink, "Effect of National European Legislation on Industrial Pharmaceutical Practice," Pharmaceutical Journal (London), 215(5835) Sept. 13, 1975 p. 308.

$36_{\text {Kaluzny, opus cit. p. } 166.24}$

37 UNCTAD, opus cit. p. 47

${ }^{38}$ Ibid. 


\section{SURVEY OF PHARMACEUTICAL COMPANIES}

It was recognized that because this survey dealt primarily with sensitive areas of pharmaceutical business practice, there night be a problem in securing response from people in the industry.

Consequently, care was taken to design the questionnaire in such a way that respondents would not feel threatened, nor would they provide self-serving answers. Thus, the questions were designed to ensure that responses could be obtained from the participants without sacrificing any vital information in the process.

Appendix 4 presents a copy of the questionnaire used in this study. The first seven questions were designed to provide a profile for the responding companies in both countries, particularly in determining the type of personnel in charge of their Nigerian operation, and also in determining their vales volume in both countries for three consecutive fiscal years. It was also designed to enable readers to know the gurrent status of individual company's level of operation in areas of manufacturing. For companies which do not currently engage in manufacturing (and they are presumed to be many), mesons for such action were asked.

The questions were also designed to determine what companies produce what products and what individual companies' leading products are on the Nigerian market. 
The next four questions (\#8 through 11), were included in order to determine how much concern the companies have for product registration in Nigeria. They were also designed to derstand how much emphasis they place on the testing of products prior to marketing in order to compare their Iesponses with that portion of the Nigerian law which deals with this issue. Responses to these questions would provide an insight into the pharmaceutical companies' operations in Nigeria vis-a-vis the government regulations.

The succeeding six questions were included in order to measure the comparability between number of attempts by the pharmaceutical industry to introduce new drug products in both eountries to the number of approvals in both countries. Asponses received would provide information on the preference of the manufacturers in introducing new drugs. When the number of attempts are compared to the number of approvals, it will be possible to determine the relative difficulty in petting products approved based on the knowledge of the laws in both countries.

A mowledge of the number of United States Food and Drug Painistration unapproved drugs currently sold in Nigeria by the Industry would provide answers to the desirability of introducting products in Nigeria where the pharmaceutical laws are more relaxed. It will also provide answers to possible enticing marketing opportunity that prevails under such relaxed conditions. 
The rest of the questions are designed to determine how the United States fares with regard to trade concessions which at the moment only the United Kingdom enjoys.

Answers to a question on how the registration and drug introduction laws of both countries are comparable with each other would certainly provide a confirmation concerning what has been empirically known for a while.

Out of the sixty-five questionnaires mailed - fifty-two in the United States and thirteen in Nigeria - only six were teturned fully or partially filled out for a response rate of Bproximately nine percent.

Fourteen respondents wrote back refusing to participate in the study for various reasons. Some of them referred all questions about their operations in Nigeria to their European headquarters. However, these headquarters never responded either.

Some of the letters written by the non-participants included information that indirectly answers some of the mestions raised in the questionnaire. For example, some companies have reduced their operations in Nigeria and have Fesorted to merely exporting to that country as a result of the government policy of having forty percent participation in all foreign investments in Nigeria. Others indicated that their operations in Nigeria are in the preliminary stages and therefore they could not contribute anything of major Ignificance to the study. Some companies stated flatly that they do not make such information public as a matter 
of corporate policy.

From the six responses obtained, profiles of individual respondents will be made and where responses are incompletely pplied, information about the particular company will be 11led in, based on further research. A synopsis of the Mypanies' responses to these questions will be made with latent awareness of the limitations imposed by low response rate.

The following sections present results by questions (see Apendix 3 for a copy of the survey instrument used).

\section{rany Profile}

One of the responding companies is a subsidiary of a large corporation with diversified operations. Its operation is international in scope and has sales in the billion dollar range world-wide. It lists its world-wide sales of $\$ 400$ Million in Medical Supplies for this company for fiscal year 1975. It reports that it is against company policy to report sales by individual countries. It does not have a manufacturing facility in Nigeria because of the Nigerian government regulations and the country's political instability. It lists its major products in Nigeria as vitamins and prenatal vitamin supplements. It is also involved in marketing of antibiotics to a lesser proportion.

Another respondent is a relatively small cmpany with projected pharmaceutical sales of $\$ 190$ million in the United States for the current fiscal year. It lists projected sales 
of $\$ 1$ willion in Nigeria for the same period. The respondent for this company is the Area Director for Nigeria, himself based in the United States headquarters. It too does not ongage in any manufacturing in Nigeria. It indicates that Nigerian policy of participation in foreign investments in NGeria is particularly responsible for its action. It is involved in the sales of antidiarrheals (its number one product in Nigeria), oral contraceptives, neuroleptics, antimasmodics and antinauseants - all in order of decreasing importance.

The third company is one based in the Southeastern United States. The person in charge of Nigeria is the Director of Operations for Middle East and Africa. It is a company which specializes in Cough and Cold Medicines in both countries under consideration. It lists other products sold in Nigeria as muscle relaxants, gastrintestinal analgesics, antidiarrheals and digestives. It does not report sales both in the United States and in Nigeria. However, sales in the United States are in the hundreds of millions of dollars. This company does not manufacture pharmaceuticals in Nigeria because "sales (in Nigeria) are not large enough to support a factory."

The fourth company is a relatively small one based in Worth-Tastern United States. Sales volume reported shows a consistent decline over a three year period. It has its headquarters in Europe and it indicates that its operations in Nigeria are controlled through the European head office. The headquarters never responded to requests for information. 
Its moducts are exported to Nigeria and it deals primarily in local anesthetics in the Nigerian market.

The fifth respondent is the Public Relations Officer for the entire company. He represents a large company based in the North Eastern United States. He states that sales are not broken down by product class - a system very unusual in the Marmaceutical industry. It also indicated that its sales in the various overseas countries are not made public. It is a company with a relatively large operation in Nigeria.

It does not manufacture its products in Nigeria because, says the Public Relations Director, "the market is currently adequately supplied." Its major products in Nigeria are antibiotics, appetite stimulants, anthelmintics, antihypertensives and lastly, antiarrythmics.

The sixth and the last company which responded has its Meadquarters in New York City. It is highly involved in the Nigerian market. It has a $\$ 4$ million factory opened recently in Lagos, Nigeria. It is highly specialized in the production and sale of antibiotics. It is also involved in other areas such as in anthelminthics, antiseptics, vitamins and antidiarrheals - in that order. The responding person is the Divisional Manager who is based in Lagos, Nigeria. His was the only response received out of the thirteen questionnaires thled to Nigeria. He too did not make available his company's eales figures from the Nigerian market.

The responses received were from pharmaceutical companies with wide variety of therapeutic class of drugs. All the 
ponding companies are international in scope. Most of them engage in exportation of drugs to Nigeria. Only one of them has a mufacturing facility in Nigeria. Only one of them listed sales volume in the United States over the three periods requested for. One other listed sales in both countries. Five of the six companies do not manufacture pharmaceuticals in Nigeria, some for economic reasons and some for political and legal reasons.

\section{GOVERNMENTAL RESTRAINT ON MARKET ING}

\section{wal of Drugs before Marketing}

The Nigerian Government through the provisions of the and Drug Decree of 1974 requires that all companies obtain governmental certification before marketing. Four of the five companies responding to this section of the questionnaire indicated that their companies do get approval from the Nigerian Government before marketing their products. One indicated that it does not have to obtain such an approval, a practice which is inconsistent with Nigerian law. Three reasons may be attributed to this practice: (1) The company's ponding officer is the Public Relations Director who may not know what the situation is like in Nigeria, but has to respond to the questionnaire perhaps because of pressure from aperior officers in the company; (2) The company is deviating from normal practice because of an apparent lack of adequate mforcement of this portion of the pharmaceutical law; 
(3) The company is taking advantage of the law which specifies that drugs approved for sale in the country of manufacture may be sold in Nigeria but not before obtaining a license to to so. Careful analysis of the company's answers to the reaining questions, however, supports the conclusion that the latter two of the three reasons enumerated above best explain the company's actions.

\section{H's Liaison Officer with the Government}

In the United States, most drug companies, it is presumed, have public relations and government relations officers who serve as liaison between the company and the government. This by itself emphasized the importance of rapport between mpanies and the government. It is even more important in areas where approval of drug products for marketing are desired.

One of the companies indicated that the distributing Pirm in Nigeria acts as the liaison between the company and the sovernment. Two companies indicated that they do not have an officer on their staff and two others indicated that they do.

It can be suggested that: (1) These companies, partieularly those who do not have such officers on their staff Ainply cannot afford the "luxury" of keeping such a staff on their payroll in Nigeria; (2) Some other company personnel in the company is responsible for such activities and therefore it will be a waste of employees' time and the company's money. However, it all boils down to one thing, that product 
registration in Nigeria to those companies may not be of major concern.

\section{muired on Products Before Marketing in Nigeria}

The Nigerian Food and Drug Decree requires only the proof of safety before a drug can be approved for marketing. However, the United States through the provisions of the Drug and Cosmetics Act requires the proof of safety as well as efficacy before a product can be approved for marketing in the United States.

The safety requirement is embodied in the series of pre-marketing testing which all potential new drugs go through in the United States. This question is asked as Lollows:

(a) --.-toxicology

(b) ----clinical

(c) ----efficacy

(d) ----safety

(e)----stability

(f)----other

This question was asked in order to find out if the pharmaceutical companies do conform to the requirements as specified in the Food and Drug Decree. It is designed to deffermine the standard of quality demanded of the drug industry as understood by them. As demonstrated in Chapter IV., the Food and Drug Decree consists of many loopholes that give room for unethical practice by some in the industry who 
may desire to do so.

General agreement on the types of tests required of wpondent would be a positive indication that they, at least, understand the law, and in all probability they would abide by it.

One of the responding companies indicated on the questionnaire that clinical, efficacy, stability and other tests besides toxicology and safety are performed. Possible tests that may fall under the "other" category couldbe any or all of the following terratogenic, bioavailability, pharmacokinetics, etc.

The Nigerian based respondent listed the following: toxicology, efficacy, safety, stability and other tests except clinical which he indicated is performed "sometimes". Dther companies either did not respond or indicated on the questionnaire that data were not available. One of the repondents indicated that no tests were required as long as "clinical support is available from elsewhere."

It can be seen from the first case above that "safety" and "fexicology" are not indicated as any of the tests required on potential drug products in Nigeria. The latter company (the only response from Nigeria), indicated that all tests except "clinical" (which is performed "sometimes"), are performed on its products before marketing.

It can be seen from these responses that there is no general agreement among the participating companies on the various kinds of tests which have to be performed on potential 
new products in Nigeria. In contrast, as demonstrated in Chapter IV, these tests are embodied in a battery of clinical and animal testing as required by the provisions of the Investigational New Drug (IND) and the New Drug Application (NDA) in the United States.

From these responses, these is evidence to suggest a general lack of understanding of the various drug laws of Nigeria among the respondents, particularly, those laws that deal with drug manufacturing. Such a lack of understanding wight be explained as follows:

1. Nigerian laws do not clearly delineate tests that have to be performed on potential new drugs and therefore such decisions are dependent on the industry's ethical values.

2. Nigeria's health delivery system cannot afford the "Iuxury" of such tests and some of the drug companies recognize this and therefore perform such tests as they deem fit.

\section{Drug Approval in Both Countries}

Companies were asked about the approval rates of drugs in both countries in order to determine if conditions are such that international drug companies would be encouraged to introduce drug products in Nigeria before doing so in the United States.

Out of the three which responded to the questions, one indicated that out of four applications submitted in the period between 1974 and 1976, three were approved and two 
of the approved drugs are actually on the market. Another one stated that out of four submitted, all four were approved for wrketing and all four were actually on the market. The Nigerian-based responding company stated that nine applications were submitted and all nine were approved for marketing in Nigeria. Six of these products are currently being sold in Nigeria.

An even more limited response rate was received regarding United States approval. One company stated five applications were submitted to the Food and Drug Administration during this period, only one of them which is currently on the market was approved for marketing.

None of those who responded to the first set of questions about approval rate in Nigeria also responded to the latter three about the United States approval rate. This makes it difficult to make the comparison desired. The lack of response to either one set of questions or the other is not likely to be a happenstance - except in the case of the Nigerian spondent which believed that the answers to the second set of questions could only be supplied by the headquarters.

The approval rate in Nigeria is better than 90 percent for the three companies which supplied this information. Over the three year-period, a total of seventeen applications were made, sixteen of these were approved, and a total of twelve products out of the sixteen approved are currently on the market. This is a success rate of approximately 70 percent between the development of new drug products and the 
actual marketing in Nigeria.

As seen from Chapter $v$, Table 4 of this study, the number of new drugs introduced into the United States market has declined from 400 in 1957 to 87 in 1968. Seventy percent of all new discoveries never make it beyond the laboratories.

This study has found that high approval rates were achieved in Nigeria. However, limited evidence obtained for the Dmanies' United States operations are simply inconclusive.

\section{A States Unapproved Drugs in Nigeria}

Questions 18,19 and 20 of the questionnaire are designed to deal with the marketing of FDA-unapproved drugs in foreign Duntries, particularly Nigeria. One of the respondents Indicated that out of the four or five such drugs in foreign markets, three are in Nigeria. None of the three was completely leveloped in the United States. "Some work on each was done in the United States." Another one of the respondents stated that "specific data (on unapproved drugs) were not arailable (but the number of such drugs) was believed to be few." None of them, it indicated, is on the Nigerian market, and none was developed in the United States. One other pompany indicated that no United States unapproved drug is in any foreign market.

\section{Dility of United States-Supplied Data}

Two of the responding companies indicated that data tained from and analyzed in the United States are satis- 
actory to the Nigerian officials "most of the time".

The responses of these companies suggest that information provided on specific drugs in the United States are readily accepted by the Nigerian officials. However, limitations imposed by low response rate makes it very difficult to be conclusive.

\section{rison Between the Two Systems}

This is the only question responded to by all the participants and there is a general agreement that new drug introduction legislation is more difficult in the United States than in Nigeria. 


\section{CONCLUSION}

\section{ral Differences}

The United States, when compared to Nigeria, has approximately three times the population, thirteen times the physical size, fifty times the Gross National Product and is cereral times greater in technical and scientific advancement. The United States is approximately 200 years older than Nigeria, but both gained their independence from the United Kingdom. Nigeria's present general level of development is comparable to the United States in the 1930s, particularly in areas of rmaceutical laws.

Life expectancy in Nigeria is estimated to be about 40 years compared to about 72 in the United States. Nigerians are afflicted with preventable diseases such as malaria, tetanus, meningitis, diarrhea, cholera, and so on while the United States is afflicted with physiological dysfunctions and disorders reflective of their life expectancy.

Twenty-nine of the 50 states in the United States surpass Nigeria in the number of pharmacists, while 27 states have a greater number of physicians, and all 50 states have more dentists. The United States surpasses Nigeria in per capita Pgures in all categories of health professions.

\section{1 and Pharmaceutical Practice}

The Nigerian native doctors play a powerful role in health 
care delivery. But the people are becoming more sophisticated in their health care demands and are seeking care from less primitive sources (physicians, dentists, pharmacists, etc.). where a scientific approach is more prevalent.

There is considerably less distinction between the practice of the Nigerian physicians and pharmacists and their counterparts in the United States; but relations between these two groups are just as subtle. Although there are clear distinctions in the statutory limits on the practice of either profession, there is some overlap in their practice as seen in this study. It has been suggested in this study that there may be flaws in the enforcement mechanism of the laws enacted to guide the practices of these professionals.

\section{tion of Pharmaceutical Laws and Practice}

Although pharmaceutical laws and practice evolved in both countries in different time frames, the general development took place in similar forms. In both countries, the pharmacy profession was subjected to intimidation; in Nigeria by the national government until 1969, and in the United States by the medical profession at much earlier times.

The laws have developed through evolutionary means in the United States, but in Nigeria, the pace has been in fact, almost revolutionary at certain points in history. Laws have been enacted in the United States mostly as a result of Praumatic national episodes (e.g. elixir sulfanilamide) or international experiences (e.g. thalidomide). On the contrary, 
in Negeria laws have been enacted mostly as a result of major rends in pharmaceutical laws of the United Kingdom or the United States.

\section{arnment Controls}

The controls imposed on the pharmaceutical industry's activities the world over are escalating in a "leap-frogging" motion. The escalation is greatest in the United States where most of the world production and consumption of drugs are carried out.

Although drug consumption levels in Nigeria are insigniIlcant when compared to the United States, the same trend in escalation of drug laws is shaping up gradually. However, the drug laws enacted are full of many loopholes which could make the enforcement of these laws very difficult.

They also contain many confusing sections that make the laws difficult to understand. Says $\underline{\text { SCRIP }}$ in its comments about section $1(1)(c)$ and section $4(b)$ of the Food and Drug Decree that "while one may not sell an article of food which consists wholly or in part (inter alia) of "filthy, disgusting, potten or diseased substance", it would appear that the only restriction for cosmetics are filth, decomposition and foreign matter. A cosmetic which contains a "disgusting" substance seems to be OK."

Similar comments can be made regarding safety requirements imposed by the Food and Drug Decree. It appears that as long as the premises in which drugs are manufactured are 
clean, the safety of the drugs is guaranteed.

In the United States, the control of the production and distribution of drugs is charged to several government agencies; but in Nigeria only one agency of the government is responsible.

Although there is no evidence of widespread illegal practices by the pharmaceutical industry, conditions such as menforced price laws, lack of adequate controls on advertising materials, inadequate controls on manufacturing of drugs, are conducive to such practices. These conditions are similar to those existing in some of the developing nations of South Merica where evidence of illegal and unethical practices have been seen.

\section{ATTITUDES OF PARTICIPANTS}

The six respondents represent only a small section of the armaceutical industry in Nigeria. Most of the respondents and indeed many of the companies operating in Nigeria are only engaged in the preliminary stages of potentially large marketing operations and therefore appear to be reluctant to upply needed data for fear of giving out trade secrets. Many of the respondents do not have manufacturing facilities and operate only by importing products from overseas countries - using the services of distributors. Generally, the responding companies have a reserved feeling about fuking large capital investments in Nigeria because of the political climate and also because of the incessant search by the government for regulatory forces on the Nigerian 
Industrial front. Others see a hope in the Nigerian market particularly because of the recent surge in business, but -ill wait and watch until the time is ripe when conditions become sufficiently promising to warrant a local capital investment.

There are wide insonsistencies between the drug laws of Nigeria as seen in previous chapters adn the responses of the participating companies. These inconsistencies suggest that there is general lack of understanding of parts of the Food Drug Decree of 1974.

From the responses obtained, it appears that new drug Introduction in Nigeria is of no major concern to the drug companies. Overall approval rate in the United States for the three periods requested is approximately eight percent for the entire industry compared to a rate of more than 90 percent for the companies which responded.

At least two of the responding companies indicated that they are marketing some United States FDA unapproved drugs in foreign markets. One of the two indicated that it has three such products on the Nigerian market. All the reppondents agreed that new drug introduction legislation is much easier in Nigeria than in the United States.

Although there is a significant difference in the approval rates of drugs in the United States and Nigeria, the number of companies that participated in the study has made it Afficult to make any conclusive report. However, it can be aggested that approval rates in Nigeria appear to be 
Mgher. In addition, all respondents perceive drug introduction legislation to be less stringent in Nigeria.

RECOMMENDATIONS FOR FURTHER STUDIES

This study has been hampered by a low response rate to the questionnaires. But its value cannot be underestimated for the reason that it opens up several areas that can be investigated upon much further and at a broader scale. Wurther studies can be embarked upon as case studies on selected companies that enjoy the confidence of the investigator. 


\section{Appendix 1}

IETTER OF INTRODUCTION 


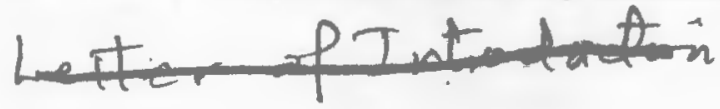

Dear Mr.

All facets of the health care industry, particularly the pharmaceutical industry, are constantly reminded of the controls imposed by government.

In order to measure the impact of some of these statutory and regulatory provisions on drug product marketing in the domestic and foreign markets, a study is being conducted by the University of Rhode Island Department of Pharmacy Administration.

Since the principal investigator for whom this study is a thesis project is a Nigerian national, the comparisons are between the United States and Nigeria. It is particularly significant that this research is being conducted during the implementation phase of the Third National Development Plan of Nigeria.

Your cooperation and response will help to make this a meanIngful and useful study, the report of which might provide insight into and focus upon the nature of the existing conditions in the two puntries under consideration.

Please be assured that every measure will be taken to assure confidentiality of responses. Names are solely for tabulation purposes and participants will not be identified in the thesis.

oking forward to receiving the stamped, self-addressed reevelope containing your completed questionnaire very soon.

Should you have any question, please do not hesitate to write or call either signer of this letter.

Thank you.

Sincerely,

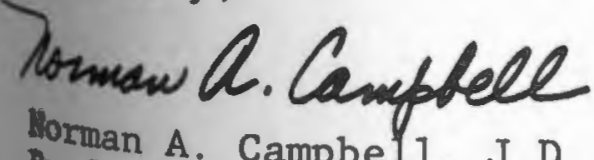

torman A. Campbell, J.D., Ph.D.

rofessor and Chairman

Enclosures
Sincerely,

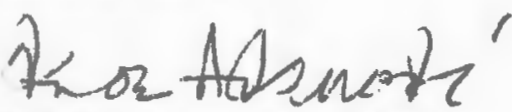

Tunde Adenodi, B.S.

Graduate Teaching Assistant 


\section{Appendix 2}

REMINDER IETTER 
KINGSTON, R. I. 02881

College of Pharmacy - Department of Pharmacy Administration - 401-792-2735

January 21, 1977

Dear Mr.

re: Questionnaire about U.S. \& Nigerian Drug Laws

We are reminding you about the questionnaire that was mailed to you on December 28, 1976.

Since the analysis of responses to the questions raised is esmential to the conclusion of the study, it is important that we receive the completed questionnaire.

If you have any doubts about any of the questions raised, please comment on such questions and procede to the others. It will serve to enlighten us on the validity of such questions.

We will be looking forward for your response.

Sincerely,

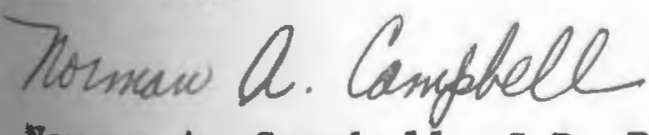

lorman A. Campbel1, J.D., Ph.D. Trofessor aind Chairman

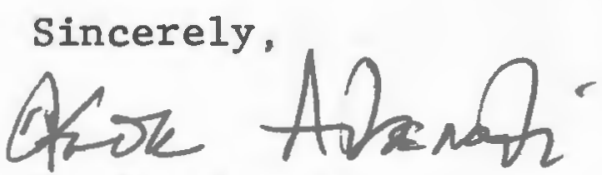

Tunde Adenodi Graduate Teaching Assistant 
Appendix 3

QUESTIONNAIRE 
1. Name of company

2. Name of respondent (optional) Title

3. Total domestic sales (Pharmaceuticals):

A) Current fiscal year (projected) \$

B) Current fiscal year -1

C) Current fiscal year -2

$\$$

$\$$

4. Total Nigerian sales (Pharmaceuticals), if applicables

A) Current fiscal year (projected) $\$$

B) Current fiscal year -1

C) Current fiscal year -2

$\$$

$\$$

$\$$

5. Does your company manufacture pharmaceuticals in Nigeria? Yes No

6. If answer to question \#5 is "No", why is your company not manufacturing in Nigeria?
A) no marketing potential
B) government regulations
C) political instability
D) not a company objective
E) reason unknown

7. What are the five leading therapeutic classes of drugs sold in Nigeria by your company? (Please list in rank order, the highest assigned a value of 1 , and the least, $a$ value of 5. )
1 .
2 .
3.
4.
5.

8. Does your company have to obtain Nigerian government approval before marketing its products in Nigeria? Yes No

9. Does your company have a governmental liaison officer regponsible for product registration in Nigeria? Yes No 
1. Name of company

2. Name of respondent (optional) Title

3. Total domestic sales (Pharmaceuticals):

A) Current fiscal year (projected)

B) Current fiscal year -1

C) Current fiscal year -2

\author{
$\$$
}

$\$$

$\$$

4. Total Nigerian sales (Pharmaceuticals), if applicable:

A) Current fiscal year (projected) \$

B) Current fiscal year -1

C) Current fiscal year -2

$\$$

$\$$

5. Does your company manufacture pharmaceuticals in Nigeria? Yes No

6. If answer to question \#5 is "No", why is your company not manufacturing in Nigeria?

A) no marketing potential

B)___ government regulations

C) political instability

D)__ not a company objective

E) ___ reason unknown

7. What are the five leading therapeutic classes of drugs sold in Nigeria by your company? (Please list in rank order, the highest assigned a value of 1 , and the least, a value of 5. )
1.
2 .
3.
4.
5 .

8. Does your company have to obtain Nigerian government approval before marketing its products in Nigeria? Yes No

9. Does your company have a governmental liaison officer refponsible for product registration in Nigeria? Yes No 
10. Are you required to conduct any tests on your products in Nigeria before distribution? Yes No

11. If "yes" what tests are required?
A) toxicology
B) clinical
C) efficacy
D) safety
E) _tability
F) other

12. How many new products did you submit applications for the Nigerian government between 1974 and 1976?

13. How many of these products were approved for marketing in Nigeria?

14. How many of these products are actually on the market?

15. How many NDA's did your company submit to the US(FDA) Food and Drug Administration between 1974-1976?

16. How many of the products were approved for marketing?

17. How many of them are on the U.S. markets?

18. How many U.S. unapproved drugs are on any foreign market?

19. Are any of the U.S. unapproved drugs on the Nigerian market?

20. How many of the U.S. unapproved drug products were developed in the U.S.?

21. Are data on imported drugs obtained from and analyzed in the U.S. satisfactory to the Nigerian officials?
A) all the time
B) most of the time
C) sometimes
Dg never

22. How would you compare new drug* introduction and registration laws of both Nigeria and the United States?
A) more difficult in the U.S. 
B) ___more difficult in Nigeria

C) ___ no difference

23. Please check the statement below if you desire to get a copy of the result of investigation. gation.

I wish to receive a copy of the result of the investi- 


\section{Appendix 4}

SCHEDULES 1 THROUGH 5 OF THE FOOD AND DRUG DECREE 


\section{SCHEDULES}

SCIHEDULE 1

Section 2

Diseases, etc. Referred to in Section 2

Alcoholism

Appendicitis

Arteriosclerosis

Asthma

Blood disorders

Cancer

Cataract

Diabetes

Cholera

Diphtheria

Disorders of menstrual flow

Disorders of prostate gland

Dysentery

Encephalilitis

Enteric fever

Epilepsy

Erysipelas

Filariasis

Gallstones, kidney stones, and bladder stones

Gangrene

Any genital or urinary diseases not mentioned elsewhere in this Schedule Glaucoma

Goitre

Hay Fever

Heart disease

Hernia

High blood pressure

Infective hepatitis

Influenza

Jaundice

Kidney disease

Leprosy

Locomotor ataxis

Loss of youth

Mcasles

Meningitis

Mental conditions

Mumps

Nervousness

Nutritional disorders 
Oloesity

\section{SCHLI)ULl: 1-conlimed}

(Onchoserciasis

I'aralysis

P'lague

Plectisy

P'ucumoni:

Polionyelitis

Rabies

Kheumatic ferer

Schistosomiasis

Sexual impotence, loss of sirility or sterility

Slecping sickness

Simallpox

Silake bitc

Syphilis

- I'ctanus

Trachomia

'Tuberculusis

Tiunumurs

'Typhoid fever

Lindulant fever

Llaers of the gastro-intestinal tract

Vencreal diseases

Yaws

Yellow ferer.

SCHISUTIJ: 2

Section 3

Druges Rellarkety to in Section 3

Parl .I

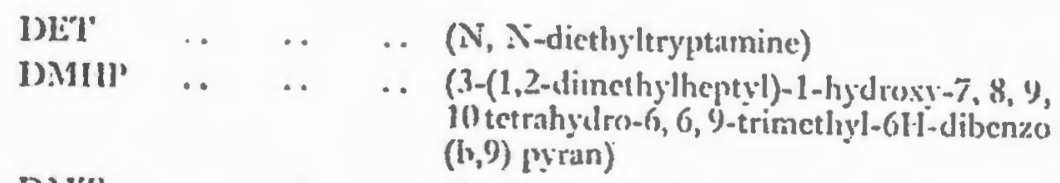

DHIV $\quad \ldots \quad \ldots \quad \ldots$ (N, N-elinethyltrypt:tninc)

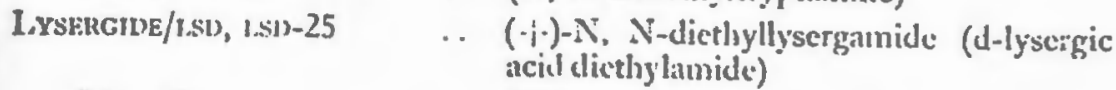

Mescalinc .. $\quad$. $\quad \ldots \quad(3,4,5$-trimelinxyphencthylanninc)

pallahexyl . $\quad \ldots \quad$.. (3-lic:xyl-1-hydroxy-7,8,9, 10-1ctrahydro-

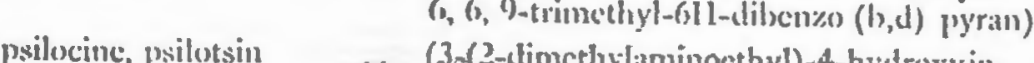

- (3-(2-climethylaminoethyl)-4-hydroxy in
itole)

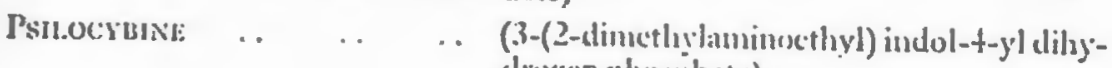
drogen phosiphiate) 


$$
\begin{aligned}
& \text { STP, DOM .. .. (2-amino-1-(2, 5-dinethoxy-4-methỵl) } \\
& \text { phenyl-propane) }
\end{aligned}
$$

\begin{tabular}{|c|c|c|}
\hline Ampнetaмis: & .. & .. (t)-2-aminn-1-phenyllprofanc) \\
\hline Dexamphetaaine: & .. & (+)-2-aminu-1-phenylprupane) \\
\hline Methampuftamine & . & (+)-2-methylanino-1-phenylpiopane \\
\hline Mrtivi.pienidate & .. & $\begin{array}{l}\text { (2-phenyl-2-(2-piperidyl) acetic acid, } \\
\text { metlyyl ester) }\end{array}$ \\
\hline Phenamerrazine & & .. (3-methyl-2-phenylmorpholine) \\
\hline P'HENCYCLIDINE & .. & .. $\{1-(1-$ phenyloylohexyl $)$ piper idine \\
\hline
\end{tabular}

Any synthetic compound or salt (howerer structuralli derived) of Amphetamine or of any substance of the like nature as Amphetaraine.

Part Bs

Amobarbital. .. . . .. (5-ethyl-5-(3-methỵlbutyl) barlituric acid)

Cyclobarbttal $\quad$. $\quad \ldots$ (5-(1-cyclohexen-i-jl)-5-cthylbarbituric acid)

Gi.utethimide .. . . . (2-cthyl-2-methflamino-1-phenyl-prop-

Pentobakbital .. . . . . (5-cthyl-5-(1-methy-lbutyl)

Secobardital. .. . . . . (5-all)l-5-(1 nethylhutyl) barbituric acid)

Amtepranove .. $\quad$. $\quad$.. (2-(diethylamine) propinghen none

Barbital, $\quad . . \quad \ldots \quad$.. $(5,5$-dictholbarbituric acid)

ethchlory-uol $\quad$. . cthyl-2-chlorovinylethin!?-ca.rbinul

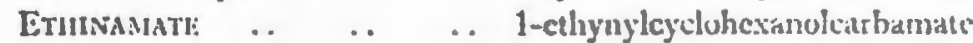

Mepromuate .. . . . 2-methy'-2-propyl-1, 3-propanediol dicarbamate

Metuaqua.ove $\quad$. . . 2-methyl-3-o-tolyl-t(3H)- quinazolinome-

MetuY .PU:

Meruypryton .. . . . . 3, 3-diethyl-5-methyl-2, t-pipcridiune-

Prenomardital. .. . . 5-ethyl-5-phenylbarbituric acial

Pipranrul. $\quad$. $\quad$. $\quad$. 1,1-diphengi-1-1-(2-piperidyl) methanol

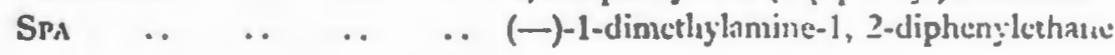

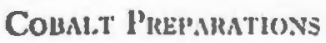

Cycl.jzine

SUlpilamethoNyDinziNe

Sut.PHAMIMT:THOXIN:

AMINOPYrinf, AND DIPYRUN:

ACECARISROMIAI.

Carmiom.M.

Bromisova.

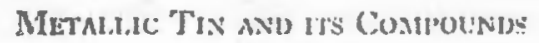

Hexachlokom HaNE: 


A $206 \quad 1974$ No. $35 \quad$ Food and Drugs

Part B-cominued

Eltpten (2-(P-laminuphenyl)-ethylglytarimide)

Meci.ozine

Bituronot. 2. 2-thiubis (4, 6-dichlorophenol)

IMIIPRAMINE

Erocaine

Nigonovial

Xanazolc Acid or Xenalamine

Dithlazanine Jodine.

Chlorpinintroraine

Crclanlates, Cyclohexyiemine and tieir Dfrivatives

Comphetamines

Cinoramphenicol and its I'reparations

Caffeine $P$

EPHEDRIN aNd ITS SALT

\section{SCHEDULE 3}

Section 5

\section{Publications referred to in Section 5}

Pharmacopoeia Internationalis

Any other pharmacopneia published under the authority of a recognised medical or plarmaccutical council of any country.

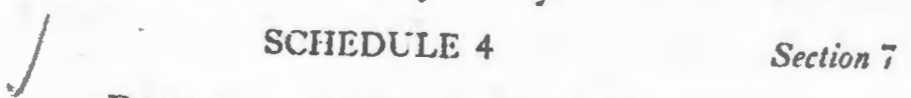

Drugs referren to ix Section 7 (1)

Liver extract in all forms

Insulin in all forms

Anterior pituitary cxtracts

Radioactive isotnpes

Living vaccines for oral or parenteral use

Drugs preparcel from micro-organisms or viruses, for parenteral use

Sera and drugs analogens thereto, for parenterul use

Antibiotics for parcuteral use.

\section{SCIEDULE 5}

\section{Section 7}

Arsphenaminc

Drugs referriad to ix Section 7 (2)

Dichloropluenarsine hydrochloride

Neoarsplicnaminc

Oxoplenarshine hydrochloride

Sensitivity discs and tablets

Sulpharsphenamine 


\section{BIBLIOGRAPHY}

BOOKS

Arnow, L. Earle, Health in a Bottle: Searching for the Drugs that Help, J.P. Lippincott (Philadelphia and Toronto), 1970.

Egboh, Andrew A., History of Pharmacy in Nigerias 1871-1971, Literamed Publications Nigeria Ltd., 1972

Egboh, Andrew A., Textbook of Forensic Pharmacy in Nigeria, Literamed Publications Nigeria Ltd., 1974

Kaluzny, Eugene L., Pharmacy Law Digest, Douglas McKay, Inc., 1976-1977.

Pharmaceutical Manufacturers Association, Prescription Drug Industry: Factbook 176, Published by PMA, 1976 ed.

Pettit, William, Manual of Pharmaceutical Law, 3rd ed. Macmillan Company, New York, Collier-Macmillan Itd., London, 1962.

Smith, Mickey C., Principles of Pharmaceutical Marketing, 2nd ed., Lea and Febiger, Philadelphia, 1975, p. 395.

Sonnedecker, Glenn, Kremer's and Urdang's History of Pharmacy, J.P. Iippincott Company, 1963.

GOVERNMENT PUBLICATIONS

Federal Ministry of Economic Development (Nigeria), Federal Office of Statistics, Third National Development Plan, 1975-1980: Health, 1974

Federal Ministry of Information (Nigeria), Nigerian Handbook: 1963 Census, 1970.

Trod and Drug Decree No. 35, (Nigeria), 1974.

Igerian Enterprises Promotion Decree No. 4, 1972, Supplement to Official Gazette Extraordinary No. $10,1272$.

Rhode Island Department of Health, Division of Professional Regulations, Comparison of Selected Health Professions, 1974. 
United Nations Conference on Trade and Development (UNCTAD)

Committee on Transfer of Technology. Major Issues in

Transfer of Technology to Developing Countries: A Case

Study of the Pharmaceutical Industry, Oct. 8, 1975 TD/B/C.6/4

U.S. Department of Commerce, Domestic and International

Business Administration. Foreign Economic Trends and their Implications for the United States, FET 75-100 1975.

U.S. Department of Commerce, Bureau of International Commerce. Foreign Trade Regulations of the Federal Republic of Nigeria, OBR 72-049, Sept. 1972.

U.S. Department of Commerce, Domestic and International Business Administration. Marketing in Nigeria OBR 7466,1974 .

U.S. Department of Commerce, Domestic and International Business Administration. Selling in Nigeria OBR 73-41 1973.

U.S. Department of Commerce, Domestic and International Business Administration. Global Market Survey. Export Opportunities for Materials Handling Equipment, Nigeria Jan. 1974.

U.S. Department of Health, Education and Welfare, National Center for Health Statistics. Health Manpower: United States 1965-1967, Series 14, No, 1

JOURNALS AND MAGAZINES

Bender, George, "Evolution of American Pharmacy 1776-1876." NARD Journal 98:11 (June 7, 1976): 34-38.

Connelly, William, "The Pharmaceutical Potential in Nigeria." Medical and Marketing Media (Oct. 1975): 18-23.

troit et Pharmacie: International Information Bulletin (1974):9

de Haen, Paul, "Compilation of New Drugs 1940-1975." Pharmacy Times (March 1976): 40-76.

Egboh, Andrew A. "Pharmacy Practice." Pharmaceutical Journal (Nigeria) (Jan./April, 1973): 29-35.

Dkwunife, Peter, "Employed Pharmacists Owning Shops: Personal Communication I." The Journal of Pharmacy (Nigeria) $5: 3$ (July-Sept., 1974): $39-40$. 
Flanningan, James, "Nigeria: Where the Action really Is." Forbes (Dec. 1, 1976): 51-61.

IuS. Pharmaceutical Market Newsletter (Jan. 13, 1975).

IMS. Pharmaceutical Market Newsletter (May 5, 1975).

IMS. World Drug Market Manual Section 1 (1975): $14: 5$.

Kouadvi, Bernard. "African Traditional Pharmacopoiea."

African Journal of Pharmacy and Pharmaceutical Sciences Inc.e (West African Pharmacist) (June 7, 1972) 2.401-403.

Mayler, H. "Report on Transfer of Technology." Pharmaceutical Journal, (Iondon) (July 26, 1974): 59-60.

Opayemi, Lai. "Drug Distribution in a Developing Country: Nigeria." Journal of Medical and Pharmaceutical Marketing (Nigeria). 4:6 (Sept-0ct. 1976): 309, 315-320.

Pink, J. "Effect of National European Legislation on Industrial Pharmaceutical Practice." Pharmaceutical Journal (London). 215:5835 (Sept. 13, 1975) $\frac{308-312 .}{30}$

Rosner, Martin M. "U.S. Pharmacy and European Drug Legislations." Journal of American Pharmaceutical Association, NS $12: 12$ (Dec. 1972): 627-628.

Shannon, Michael C. "How Apothecaries Kept the Colocial Forces Supplied with Drugs Despite Severe Hardship." Pharmacy Times (Nov. 1975), 85-94.

West Africa, Aug. 30, 1976.

West Africa, June 28, 1976.

THESES

Ansari, Omer. "Marketing and Pharmaceuticals in India." Master of Science, Brooklyn College of Pharmacy, Long Island University, 1963.

Bundukamara, Moses A. "A Comparative Study of the Practice of Pharmacy in Sierra Leone and in the United States of America." Master of Science, Brooklyn College of Pharmacy, Long Island University, 1963.

NEWSPAPERS

Daily Times of Nigeria, Feb. 1, 1975. 
Daily Times of Nigeria, March 22, 1975.

New York Times, Tues. May 25, 1976.

SCRIP, Sept. 13, 1975. 